Review

\title{
Iron Oxide Nanoparticles for Biomedical Applications: A Perspective on Synthesis, Drugs, Antimicrobial Activity, and Toxicity
}

\author{
Laís Salomão Arias ${ }^{1}$, Juliano Pelim Pessan ${ }^{1}$, Ana Paula Miranda Vieira ${ }^{1}$, \\ Taynara Maria Toito de Lima ${ }^{2}$, Alberto Carlos Botazzo Delbem ${ }^{1}$ (iD and \\ Douglas Roberto Monteiro 2,* (iD) \\ 1 Department of Pediatric Dentistry and Public Health, School of Dentistry, Araçatuba, \\ São Paulo State University (Unesp), 16015-050 Araçatuba/São Paulo, Brazil; laisarias@hotmail.com (L.S.A.); \\ jpessan@foa.unesp.br (J.P.P.); anapaula.mvieira@hotmail.com (A.P.M.V.); adelbem@foa.unesp.br (A.C.B.D.) \\ 2 Graduate Program in Dentistry (GPD-Master's Degree), University of Western São Paulo (UNOESTE), \\ 19050-920 Presidente Prudente/São Paulo, Brazil; taynaramaria@hotmail.com \\ * Correspondence: douglasrmonteiro@hotmail.com; Tel.: +55-18-3229-1000
}

Received: 16 April 2018; Accepted: 7 June 2018; Published: 9 June 2018

\begin{abstract}
Medical applications and biotechnological advances, including magnetic resonance imaging, cell separation and detection, tissue repair, magnetic hyperthermia and drug delivery, have strongly benefited from employing iron oxide nanoparticles (IONPs) due to their remarkable properties, such as superparamagnetism, size and possibility of receiving a biocompatible coating. Ongoing research efforts focus on reducing drug concentration, toxicity, and other side effects, while increasing efficacy of IONPs-based treatments. This review highlights the methods of synthesis and presents the most recent reports in the literature regarding advances in drug delivery using IONPs-based systems, as well as their antimicrobial activity against different microorganisms. Furthermore, the toxicity of IONPs alone and constituting nanosystems is also addressed.
\end{abstract}

Keywords: biotechnology; drug delivery; iron oxide nanoparticles; magnetic nanoparticles

\section{Introduction}

The development of nanotechnology has provided resources to various applications in the medical field, leading to significant advances in terms of diagnosis, biological detection, therapy and drug delivery [1-5]. In this context, magnetic nanoparticles comprise important characteristics that make them attractive for a variety of biomedical applications, including contrast agents in magnetic resonance imagining (MRI) [6], cell separation and detection [7,8], treatment for hyperthermia [9] and drug delivery [10]. Specifically, iron oxide magnetic nanoparticles (IONPs) are physically and chemically stable, biocompatible and environmentally safe [11], thus presenting unique characteristics for clinical applications. However, when IONPs $\left(\mathrm{Fe}_{3} \mathrm{O}_{4}\right.$ (magnetite) or $\gamma-\mathrm{Fe}_{2} \mathrm{O}_{3}$ (maghemite)) reach smaller sizes (about 10-20 $\mathrm{nm}$ for iron oxide), superparamagnetic properties become evident, so that the particles reach a better performance for most of the aforementioned applications [11,12].

Despite the growing body of evidence attesting their biomedical usefulness, superparamagnetic IONPs are still in early stage of clinical investigation, with studies pointing out to the need for their improvement prior to their commercialization. Most of clinical trials with IONPs have been developed within the last decade, being MRI imaging the main application assessed $[13,14]$. The number of clinical trials indexed on clinicaltrials.gov [14] under the term 'iron oxide nanoparticles' comprises fourteen protocols. Of these, four are completed, four are still active, one was withdrawn, four were suspended or terminated, and one has an unknown status. Published data from one of those clinical 
trials showed that IONPs succeeded to act as contrast agent for MRI for the assessment of cellular myocardial inflammation following acute myocardial infarction, with no described adverse effects to the patients [15].

Issues related to biocompatibility, toxicological and immunological parameters are other challenges that need to be addressed. Data on methods of synthesis show that IONPs functions are directly related to size, shape, coating and stability of these nanoparticles [16]. As an example, large nanoparticles (>200 $\mathrm{nm}$ ) are easily cleared by the reticuloendothelial system [17,18], while particles smaller than $10 \mathrm{~nm}$ are easily excreted from the body through existent pores of the kidney's basal lamina [19], what reduces their blood-circulating time. Further, hydrophobic and negatively charged nanoparticles tend to suffer proteic opsonization and are quickly recognized by phagocytic cells [20], also resulting in faster clearance. These and other IONPs limitations, such as oxidation and cell toxicity, can be overcome by an adequate surface-coating, implying that the success of a IONPs-based nanosystem is also directly related to the properties of the coating material. Different organic and inorganic coatings, including natural and synthetic polymers [21-23], surfactants [24], gold [25], silica [26] and peptides [27] have been investigated in studies showing that shape, spatial configuration and nature of the coating play an important role on the nanosystem's performance.

This review provides conceptual information on methods of IONPs synthesis, addressing the main advantages and disadvantages, and drugs bound to IONPs in the production of drug-delivery nanosystems. The latest updates on bioapplications, translational advances, and the employment of IONPs on antimicrobial therapeutic alternatives are also covered, bringing new perspectives on IONPs investigations. Finally, a set of considerations is made on IONPs toxicological aspects, as well as advances on coating strategies to elaborate more biocompatible nanosystems.

\section{Synthesis of IONPs}

There are three main routes for the synthesis of IONPs: chemical, physical and biological. These have been investigated in order to produce more stable, soluble, biocompatible, and shape and size-controlled nanoparticles [28]. This review presents an overview on the most common methods of synthesis, highlighting advantages and disadvantages of each method.

\subsection{Chemical Routes}

\subsubsection{Co-Precipitation}

Among the chemical methods of synthesis of IONPs, the aqueous co-precipitation is the most commonly used $[18,29]$. Shortly, salts of $\mathrm{Fe}^{2+}$ and $\mathrm{Fe}^{3+}$ ions suffer co-precipitation in a fairly basic solution (molar ratio 1:2) at room temperature or under heat [29-32]. In general, this is a convenient and low cost method that enables rapid large-scale production. However, the resulting nanoparticles present problems of aggregation and large size distribution, which is common in aqueous routes [33], in addition to poor crystallinity and tendency to oxidize, thus compromising their magnetic properties [18,30].

Given that base concentration, temperature, $\mathrm{Fe}^{2+} / \mathrm{Fe}^{3+}$ proportion, value and ionic strength of the media, order of the reactants and the use of surfactants are factors that may interfere with the control of particle size, shape, composition and magnetic properties [34,35], recent studies have adapted the co-precipitation method in order to improve the properties of the nanoparticles [36-39]. For instance, through variations in the $\mathrm{pH}$ of the precipitates and in the amount of sodium hydroxide, spherical IONPs of different sizes can be obtained [40], taking advantage of the linear relation between IONPs diameter and $\mathrm{pH}$, probably due to nanoparticle aggregation.

\subsubsection{Microemulsion}

The microemulsion method acts confining the production of nanoparticles inside a nanosystem that combines a stable isotropic mixture of oil and water, whose interface is stabilized by a monolayer of surfactant, sometimes combined with a co-surfactant $[31,41,42]$. The size of the microemulsion, whether 
direct (oil dispersed in water) or indirect (water dispersed in oil), may be controlled by adjusting the ratio of water, oil and surfactant, which consequently leads to the IONPs size control $[29,43,44]$. Microemulsion experiments demonstrated that the nature of the surfactant, concentration of $\mathrm{Fe}^{2+} / \mathrm{Fe}^{3+}$ ions, as well as the temperature and the $\mathrm{pH}$ value strongly influence the nanoparticles size distribution and, consequently, their magnetization [33]. Despite the narrow size distribution that this method provides, it presents certain limitations for biomedical purposes, including requirements of low temperatures and large quantity of oil, which limits large scale production. Moreover, surfactants adhered to IONPs are difficult to remove $[17,31,42]$.

\subsubsection{Hydrothermal and Solvothermal Syntheses}

Through the hydrothermal method, iron precursors are exposed to vapor in a sealed container, under high pressure and temperature conditions in an aqueous medium, creating uniform IONPs [17]. Under these conditions, the controlled oxidation of $\mathrm{Fe}_{3} \mathrm{O}_{4}$ and the mineralization of $\mathrm{Fe}^{3+}$ ions occur. When the aqueous synthesis methods generate particles with low crystallization, the solvothermal method can be used, which consists in replacing water by other organic solvents, allowing the formation of monodisperse IONPs with high crystallinity and controlled shape $[28,35,45,46]$. However, such methods last much longer (hours to days) in comparison to the microemulsion method [11,29].

\subsubsection{Thermal Decomposition}

The thermal decomposition is a non-aqueous synthesis in which organometallic compounds such as $\mathrm{Fe}(\mathrm{Acac})_{3}, \mathrm{Fe}\left(\mathrm{C}_{2} \mathrm{O}_{4}\right) \times 2 \mathrm{H}_{2} \mathrm{O}, \mathrm{Fe}\left(\mathrm{CH}_{3} \mathrm{COO}\right)_{2}$ or ferrocene suffer decomposition in a high-boiling organic solvent (or via solvent free) in the presence of stabilizing surfactants like aliphatic amine and fatty acids [30,47]. This method circumvents the limitations of co-precipitation by generating high quality IONPs with close distribution and particle size control, as well as improving their magnetism and degree of crystallinity $[30,47,48]$. This occurs due to the possibility of separating the nucleation from the growth, avoiding complex reactions of hydrolysis [29,49]. Iron oxide nanocrystals with narrow size distributions, high yield and without aggregation can be obtained by this method [50]. However, as the resulting IONPs are insoluble in water, further steps are required to make their surfaces hydrophilic and, consequently, compatible with biological solutions [18,51]. Also, a higher relaxivity and saturation magnetization can be achieved by higher temperatures and shorter synthesis reactions [52].

\subsubsection{Sol-Gel Reaction and Polyol}

The sol-gel reaction is a wet-chemical method in which iron alkoxides and salts (e.g., chlorides, nitrates and acetates) undergo reactions of condensation and hydrolysis [29,53]. Factors implicated in the process such as $\mathrm{pH}$, temperature and concentration of the reagents can interfere with the final crystallinity of the product. The main advantage of this method is the production of structures with good homogeneity and size, and high purity and quantity. However, precursors used in the reaction are costly, and the resulting nanoparticles may display high permeability and low wear resistance [54,55]. On the other hand, the polyol method uses a reduction reaction in which the polyol is heated to its boiling point, and acts as a solvent and reducing agent in a medium with iron precursors, controlling the growth of the particles [56]. Noteworthy, the size of the nanoparticles varies according with the polyol used, reaction time and concentration of iron precursor. In this sense, the size of the nanoparticles was shown to increase proportionally to the length of the glycol [57].

\subsubsection{Sonochemical}

In sonochemical synthesis, a ferrous salt solution is subjected to a high-intensity ultrasonication at room temperature, ensuring that the physical effects generated from the creation of blistering in solution generates the energy required for the reaction $[16,28]$. This method can be an unusual and versatile alternative for materials synthesis owing to short reaction times, and lack of high process 
temperature and pressure. As an example, the highest percentage of atomic concentration when functionalizing 3-amino propyl triethoxyl silane with IONPs was achieved after one minute of sonication [58]. In addition, the ultrasonic frequency may play a role in the products generated by this method, considering that the amount of the drug loaded proportionally increases with ultrasound frequency [59].

\subsubsection{Microwave-Assisted Synthesis}

Microwave-assisted synthesis is a relatively simple and recent method, in which a mixture containing the iron precursors is exposed to microwave electromagnetic radiation, causing molecule reorientation, and strong and homogeneous internal heating [16,29]. This method has several advantages such as low-cost, reduced time of reaction and narrow size- and shape-control of the IONPs [29,35], which make it attractive for cost-efficient commercial production of IONPs with appropriate solubility and biocompatibility for clinical trials [60].

\subsection{Physical Routes}

\subsubsection{Pyrolysis Method}

In pyrolysis method, gaseous (aerosol) organometallic precursors are exposed to laser radiation that transmits energy in a selective way, according to the chemicals wavelength, thus generating IONPs [61]. This route produces pure and homogeneous samples with good size control and shape distribution. It is less expensive than other methods, since it operates at atmospheric pressure [35,62]. Factors such as precursors concentration, working pressure and laser intensity directly interfere with size and magnetization of the resulting nanoparticles [63].

\subsubsection{Laser Ablation Synthesis in Solution (LASiS)}

This synthesis is triggered when a pulsed laser beam reaches the target material immersed in liquid solution, causing changes in the composition of the ablation target and in the liquid solution [64]. Although LASiS is an interesting technique for materials of different structures and compositions, this method carries problems depending on the solvent used, such as the difficulty of controlling particle size and their clustering [64]. Recent experiments, however, revealed that the use of laser ablation on phosphonates aqueous solution and bulk iron was successful in decreasing the size of $\mathrm{FeO}_{\mathrm{x}}$ crystal to few atom clusters [65].

\subsection{Biological Route}

Biosynthesis

Biosynthesis stands out as a simple, low-cost and eco-friendly route of IONPs production [66], in which plant extracts or microbial-derived products with reducing potential interact with iron precursors under stirring. The main reaction involved in this process is reduction/oxidation, and the resulting nanoparticles usually display good biocompatibility $[16,29,66]$. The IONPs biosynthesis can use iron-reducing bacteria such as Geobacter metallireducens [67] but may include many other possibilities. One example is the synthesis by the enzyme lumazine synthase (produced both by fungi and bacteria), which serves as a biological nanoreactor, synthesizing IONPs inside narrow-diameter capsid templates [68].

\section{IONPs Coating and Functionalization}

Core-shell nanosystems are often employed to attach different drugs to IONPs. The nanoparticle corresponds to the core, while shell represents the surface coating for nanoparticle functionalization, improving its stability, pharmacokinetics, biodistribution and biocompatibility [69]. Synthetic and natural polymers, organic surfactants, inorganic compounds and bioactive molecules can function as shell of IONPs, as summarized in Figure 1. 
Nanoparticles functionalization - surface coating
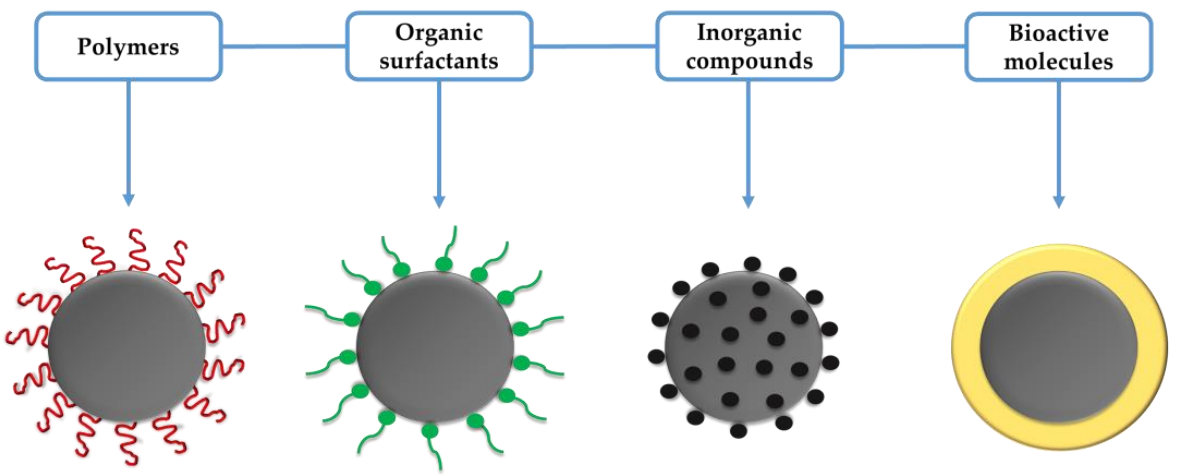

Figure 1. Schematic illustration of the main shells for functionalization of iron oxide nanoparticles (IONPs). Grey circles represent the core of IONPs.

\subsection{Synthetic and Natural Polymers}

Polymers are the most common surface coating used in IONPs, since they can prevent oxidation and confer stability to the nanoparticles [70]. The polymer nature can be synthetic, encompassing polyethylene glycol, poly(vinylpyrrolidone), polyvinyl alcohol and poly(lactic-co-glycolic acid) $[28,29,35]$, or natural, as in the case of chitosan.

\subsubsection{Polyethylene Glycol (PEG)}

PEG is a hydrophilic, uncharged polyether polymer well known for its biocompatibility [71]. It has been commonly used as IONPs-coating due to non-fouling properties, reduced blood proteins opsonization and, as a result, escapes recognition by the immune system. Such properties increase its time in blood circulation and the accumulation in the target cells/organ [28,70,71].

\subsubsection{Poly(vinylpyrrolidone) (PVP) e Polyvinyl Alcohool (PVA)}

PVP e PVA are water-soluble synthetic polymers. Specifically, PVP is derived from the monomer $\mathrm{N}$-vinyl pyrrolidone [72]. Given its biocompatible, stable and safe properties, PVP is widely used in biomedical and pharmaceutical applications [72,73]. In turn, PVA exhibits emulsifying and adhesive properties, forming a hydrogel structure that involves the IONPs by means of hydrogen bonds between the polymer chains. This leads to increases in polymer-surface interactions, preventing the agglomeration of the particles $[70,73]$.

\subsubsection{Poly(lactic-co-glycolic acid) (PLGA)}

PLGA is a copolymer of poly lactic acid and poly glycolic acid (PGA) [74] with great potential for use in drug delivery and tissue engineering. Besides presenting solubility in most of common solvents, PLGA can take different shapes and sizes, and encapsulates molecules of all sizes. Usually, higher rates of PGA (which contains methyl site groups) lead to a higher hydrophobicity and degradation of the polymer [75]. On the other hand, lactide-rich PLGA are less hydrophilic and degrade more slowly, since it absorbs less water [74]. Moreover, physical properties of PLGA are known to vary depending on different factors such as the molecular weight, which plays an important role in the drug-loading capacity on the polymer surface [76].

\subsubsection{Chitosan (CS)}

IONPs have also been coated with CS. This material is a natural, long-chain polymer, generated by the combination of 2-amino-2-deoxy- $\beta$-D-glucan with glycosidic linkages, which can be obtained by chitin deacetylation [77]. Its positive charge drives the CS carriers to the cell membrane (negatively 
charged) and its mucoadhesive properties extend the CS retention in the target sites, making it interesting for application in drug delivery systems [77,78]. Furthermore, CS is biocompatible, biodegradable and presents low toxicity [79-81].

Many CS-nanosystems have been developed over the last few years [82-87], relying on the aforementioned advantages and water solubility [88]. Coating of IONPs with this polymer does not change the thermal and magnetic properties of the nanoparticles, serving as support for drug binding [89]. Also, a one-pot synthesis in the presence of CS of low molecular weight showed that it was capable of protecting IONPs from aggregation due to the electrostatic repulsion between the positively charged nanoparticles [22].

This polymer, however, presents certain limitations as a coating material, mainly associated with the partial protonation of its amino groups in water at physiological $\mathrm{pH}$, what reduces $\mathrm{CS}$ solubility [90,91]. To overcome such issues, chemical changes can be performed in order to make CS derivatives more water-soluble [91]. A practical example is the $O$-carboxymethyl CS, which uses hydrogen bonding between water and the polymer in combination with carboxyl group to obtain water solubilization [92]. Also, a polyelectrolyte complex of carboxymethyl starch-CS can be used as a coating for IONPs, producing stable, biocompatible and mucoadhesive nanosystems [93].

\subsection{Organic Surfactants}

Surfactants (e.g., oleic acid, lauric acid) are extensively used to functionalize IONPs [54], mainly when synthesized in organic solutions. IONPs coated with dimercaptosuccinic acid (DMSA) have an anionic surface, which avoids opsonization and clearance by the reticuloendothelial system, with consequent reduction of cell toxicity [25,70]. Oleic acid and trisodium citrate are also capable of stabilizing nanoparticles by creating repulsive forces (mainly steric repulsion) to balance the magnetic and van der Waals attractive forces [94].

However, the long hydrocarbon chains of the surfactants make the nanoparticles hydrophobic, hindering their application in vivo, and require measures to prevent or reverse this aspect $[94,95]$. Investigations to overcome these limitations led to experiments with surfactant-functionalized IONPs through hydrophobic interactions, demonstrating that lower values of surfactants' critical micelle concentrations were associated with more efficient coating of the IONPs, with greater dispersion in solutions and lower nanoparticle clustering [24].

\subsection{Inorganic Compounds}

Some applications are favored in inorganic compound-containing nanosystems, such as catalysis, bioseparation, optical bioimaging and biological labeling [29,70]. Moreover, inorganic compounds have the potential to increase the antioxidant properties of bulk IONPs [33]. Silica, carbon, metals, oxides (metal and non-metal) and sulfides are the most widely tested.

$\mathrm{SiO}_{2}$ is a classical coating material for IONPs, since it has the capacity of enhancing the IONPs dispersion in solutions, and to turn them more stable and protected in acidic medium [11,90]. The silanol groups on their surface also offer perfect anchorage for ligands, providing various functional groups to the nanosystem $[16,29,33,70]$. Most of silica coatings also contribute to reduce the IONPs toxicity [26,96-98].

Carbon-based coatings have interesting features, such as chemical and thermal stability, good electrical conductivity, solubility, and serve as a barrier against IONPs oxidation, being useful for diverse applications $[28,29]$. As an example, novel nanosystem composed by magnetic carbon $/ \mathrm{Fe}_{3} \mathrm{O}_{4}$ with nanoscale zero-valent iron was able to remove $99.7 \%$ of $\mathrm{Pb}$ (II) from aqueous solutions [99].

Metal coatings can also prevent IONPs oxidation owing to their low reactivity [70]. They can bind to IONPs via electrostatic linking, forming core-shell structures that can be modified according to their functional groups and surface charges $[29,100]$. In this regard, the electron transfer between silver and IONPs in a nanosystem creates a silver coating positively charged, allowing the conjugation of different antibiotics to the silver-decorated IONPs [100]. In addition, silver coating does not alter 
the magnetic properties of the original iron oxide powder. Finally, metal coatings can also suffer modifications with compounds such as thiol to enable their linkage with diverse biomolecules [101].

Oxide and sulfide are common in IONPs functionalization, in order to stabilize the nanosystem without interfering with its magnetic features [11]. For metal oxides, it is possible that the combination of two different magnetic phases creates a new composite with pronounced magnetic properties [11]. The nanosystem can be formed by oxidation of the outer shell of the nanoparticles or it can just be additionally deposited [29]. The choice of a coating for the IONPs must take into account their intrinsic properties and the purpose of the nanosystem. For instance, $\mathrm{ZnO}$ was selected as the most appropriate compound for an anticancer nanosystem due to both its intrinsic anticancer properties and biocompatibility [102].

\subsection{Bioactive Molecules}

In this category are included bioactive structures such as lipids, peptides, and proteins $[29,70,103]$. In IONPs-based nanosystems functionalized with peptides, the biomolecules are able to maintain the stability of the nanostructures, as well as the magnetic properties of the IONPs [27,104].

Human and bovine serum albumin (HSA and BSA) are also used in biomedical and pharmaceutical applications, and can be attached to IONPs by desolvation [105]. BSA-coated IONPs has a negatively charged surface that avoids electrostatic interactions with negative biological elements such as plasma and blood cells, therefore maintaining IONPs stability [106].

While for matrix-dispersed structures IONPs are distributed in a matrix, thus preventing aggregation, in shell-core-shell they are confined between two functional materials [28,29]. In turn, Janus particles possess two compartments, one being the IONPs with magnetic properties and the other, composed by different functional molecules [107].

\section{Drugs Bound to IONPs}

Magnetic nanoparticles have greater reactive area and ability to cross biological barriers than their micrometric counterparts, which favors their use in drug delivery systems. In this context, different classes of drugs can be directly bound to IONPs or to core-shell nanosystems, as shown in Figure 2. Such binding can occur by adsorption, dispersion in the polymer matrix, encapsulation in the nucleus, electrostatic interactions and covalent attachment to the surface [5,108], aiming to improve their pharmacological properties. IONPs have been used as carriers of anticancer, alternative, immunosuppressive, anticonvulsant, anti-inflammatory, antibiotic and antifungal agents.
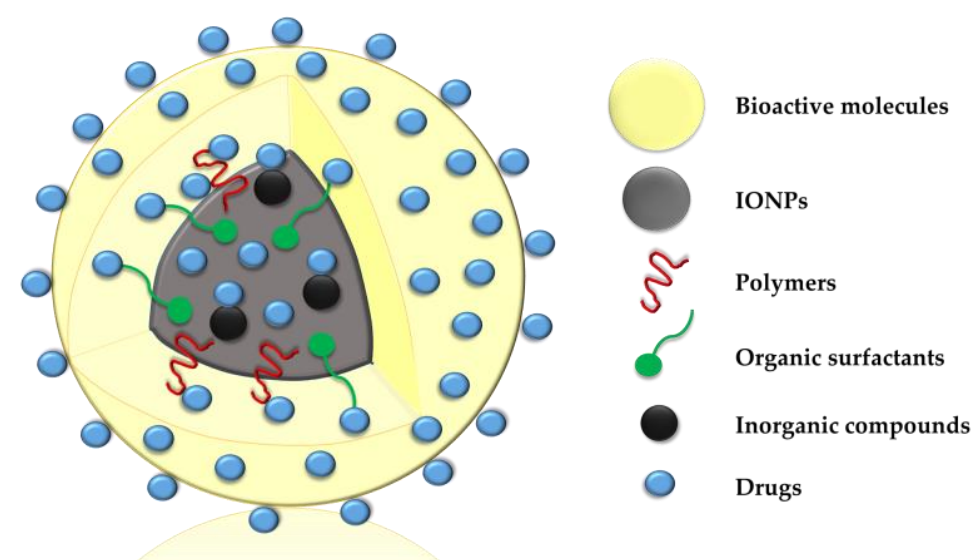

Figure 2. Schematic illustration of drugs directly bound to iron oxide nanoparticles (IONPs) or to core-shell nanosystems. 


\subsection{Anticancer Drugs}

One of the major challenges in cancer treatment is the tolerance developed throughout the therapy, which reduces response to the medicament. When a drug is bound to IONPs, this tolerance can be overcome due to a reduction of the "efflux pumps" that transport the drug to the outside of the cell [109], what ultimately promotes an increase in drug concentration in cancerous tissues [109]. IONPs-based nanocarriers are also able to reduce undesired interactions with other molecules [110] and toxic effects on normal tissues [111]. Furthermore, these nanosystems are less specific than molecules such as antibodies and peptides, thus acting on various types of cancer [111].

Over the last two years, the main anticancer drug coupled to IONPs was doxorubicin (DOX) [112-134]. This drug can be covalently bound to functionalized IONPs [123] or establish electrostatic interactions with negatively charged groups present in the magnetic nanocarriers [133]. A nanosystem with mesoporous hydroxyapatite (HA)-coated IONPs for DOX release was able to incorporate $93 \%$ of DOX from a concentration of 5 ppm [112]. In $24 \mathrm{~h}$, only $10 \%$ of the DOX was released at $\mathrm{pH}$ 7.4, while for $\mathrm{pH} 5.5$ it reached a release of 70\%, making IONPs-DOX-HA a favorable nanosystem for the treatment of acidic solid tumors [112].

Current investigations have also synthesized IONPs employing different shells with anticancer agents conventionally administered, such as $\beta$-cyclodextrin [135], carmustine [136], cetuximab [137-139], cytarabine [140], daunomycin [141], docetaxel [142,143], epirubicin [144], 5-fluorouracil [145-153], gemcitabine [22,154-158], methotrexate [159-161], mitoxantrone [162-165] and paclitaxel $[27,104,166-172]$. It is noteworthy, however, that these nanosystems demonstrate magnetic properties only in the presence of external magnetic fields to prevent agglomerations of nanoparticles [111] and to allow a satisfactory performance in the target sites.

\subsection{Alternative Drugs}

Alternative drugs may also be linked to nanosystems. Curcumin, a natural polyphenolic hydrophobic compound from Curcuma longa rhizomes, has been incorporated into IONPs for preventing and fighting cancer $[10,106,133,173-175]$. It is believed that this herbal product remains captured at the hydrophobic interface between components of surfactant-stabilized nanocarriers [133]. In this sense, Unterweger et al. [176] proposed the use of photodynamic therapy associated with the hypericin photosensitizer (a component of the plant Hypericum perforatum or St. John's wort, with antitumor properties), IONPs and dextran, concluding that this combination is a promising alternative for cancer treatment. Hypericin was covalently coupled to dextran-coated IONPs by glutaraldehyde, and the particles of this nanosystem were able to induce the death of cancer cells, besides not presenting agglomeration even after 12 weeks of storage in water [176].

Another active component of herbal origin used to fight cancer cells is berberine, which exhibits poor bioavailability in tumor sites due to the lack of hydrophilicity. To address this limitation, this compound was linked to IONPs and Sanazole, and the obtained nanosystem displayed a reducing effect on hypoxic tumor volume in mice [177]. Finally, essential oils have been bound to IONPs to improve their stabilization and reduce their volatility. Such nanostructures can be incorporated on the surface of catheters [178] or into wound dressing materials [103] in order to decrease microbial adherence and biofilm-associated infections.

\subsection{Immunosuppressives}

High concentrations of immunosuppressants may generate serious secondary complications in patients with transplants or autoimmune diseases [179]. To minimize this problem, a nanosystem composed by silica (SI)-coated IONPs was formulated to act as a carrier of mycophenolic acid (MPA), the main component of the immunosuppressive mycophenolate mofetil [180]. MPA was bound to the SI-coated IONPs by means of hydrophobic interactions, and the resulting nanosystem was biocompatible at the concentration of $0.56 \mathrm{mg} / \mathrm{L}$, with capacity of transporting up to $30 \%$ of MPA's 
weight. At this concentration, the IONPs-SI-MPA nanosystem was able to reduce the secretion of human interleukin 2 and tumor necrosis factor- $\alpha$, indicating the activation of immune cells [181]. Despite the 10-fold lower MPA supply when compared to other studies [181,182], this nanosystem promoted a similar efficacy in cytokine upregulation.

\subsection{Anticonvulsants}

Nanotechnology has also generated a novel and non-invasive approach for the treatment of temporal lobe epilepsy associated with pharmacological resistance. A nanosystem composed by anti-interleukin-(IL)-1 $\beta$ monoclonal antibody (1- $\beta \mathrm{mAb}$ ) covalently attached to IONPs functionalized with PEG was developed and injected into the caudal vein of rats with acute temporal lobe-induced epilepsy [183]. The MRI revealed a greater number of IONPs-anti (IL)-1 $\beta$ mAb-PEG in the epileptogenic tissues with respect to IONPs alone and the control group (saline solution), demonstrating a higher neuroprotective effect of the nanosystem. The effect of SI-coated IONPs loaded with the antiepileptic phenytoin (PHT) was also analyzed in an in vivo model assessing drug resistant convulsions [184]. IONPs were previously coated with SI to avoid oxidation and improve stability. Thereafter, PTH was bound to SI-coated IONPs via adsorption, forming a nanosystem capable of carrying around $250 \mu \mathrm{g}$ of PHT per $100 \mathrm{mg}$ of nanoparticles [184]. After administration of 3-mercaptopropionic acid (3MPA) in rats to induce convulsions associated with P-gliprotein cerebral overexpression [185], the IONPs-SI-PHT nanosystem was able to significantly increase the afterdischarge threshold values compared to the group of rats receiving pure saline solution, indicating its potential to reduce the neural excitability and the incidence of convulsion [184].

\subsection{Anti-Inflammatories}

The hydrophobic anti-inflammatory Ketoprofen (KTF) was encapsulated with IONPs, polypyrrole (PPL) and PEG to determine its release profile [186]. For nanoparticles without PEG, the encapsulation efficiency of $20 \% \mathrm{KTF}$ 's weight was $98 \%$, ratifying the high binding capacity of the drug, which had its complete release after three hours in phosphate-buffered saline solution. Electrostatic interactions between the positively charged PPL and the negatively charged KTF probably facilitated encapsulation, while PEG stabilized the IONPs by simple adsorption [186]. Jia et al. [187] coupled IONPs and hyaluronic acid $(\mathrm{AH})$ to a furan-functionalized dexamethasone peptide (GQPGK), aiming to target the system to adipose tissue defect sites. This dexamethasone peptide was attached to the nanostrutures via covalent bonds, and the IONPs-AH-GQPGK nanosystem presented the desired adipogenic effect on co-culture of human adipose derived stem cells, evidencing great potential for application in adipose regeneration therapies. In turn, IONPs also showed potential for acting as carrier of prednisolone to the cochlea. Intratympanic administration of these nanoparticles in conjunction with prednisolone did not promote severe injury in rats, which highlights the possibility of developing alternative nanocomposites for the treatment of auditory disorders [188].

\subsection{Antibiotics}

The emergence of highly resistant bacterial strains and the reduced alternatives to conventional antibiotics has aroused interest in the design of antibiotic-carrier nanosystems. IONPs functionalized with CS have been used as carriers of streptomycin $[189,190]$. As a physical mixture, this antibiotic showed a rapid release $(20 \mathrm{~min})$ in phosphate-buffered saline, while in the form of a nanosystem its full release was completed only after $350 \mathrm{~min}$, indicating the ability of IONPs to act in controlled-release systems [189].

Different groups of antibiotics (rifamycin, anthracycline, fluoroquinolone, tetracycline and cephalosporin) were bound by physical adsorption to silver nanoparticles (Ag)-loaded IONPs [100]. It is believed that Ag (positively charged) interacts electrostatically with the IONPs, allowing linking of these antibiotics [100]. Similarly, rifampicin, doxycycline, cefotaxime, and ceftriaxone were also attached to IONPs decorated with Ag, and the mechanisms of association varied for each 
type of antibiotic, including electrostatic binding with negative sites and hydrogen bonding [191]. Synthesis using the green sonication-assisted procedure was tested for the conception of the nanosystem IONPs-Ag-rifampicin [192]. The adsorption of rifampicin was evaluated at different Ag concentrations $(5.3,7.7,10.1,15.1$ mass $\%)$ in the IONPs-Ag nanocomposite, and the lowest and highest adsorption occurred for Ag at 5.3 and 7.7 mass $\%$, respectively [192].

Other models of therapeutic resources have also been studied, including IONPs-ciprofloxacin nanosystem [193], which may be functionalized with lactose particles [194]. Furthermore, nanosystems composed by amikacin, amoxicillin, bacitracin, cefotaxime, erythromycin, gentamicin, kanamycin, neomycin, penicillin, polymyxin, streptomycin and vancomycin directly coupled to IONPs (i.e., without involving a shell coating) have been investigated [195].

\subsection{Antifungals}

Fungal diseases are opportunistic infections that often affect immunocompromised patients and, if not properly treated, can be fatal. Since Nystatin (NYS) is one of the most commonly used fungicides, Hussein-Al-Ali et al. [196] prepared a nanosystem composed by IONPs, CS and NYS. The authors demonstrated that the release profile of NYS in a physical mixture of these isolated compounds lasted about $20 \mathrm{~min}$, compared to $1800 \mathrm{~min}$ of the IONPs-CS-NYS nanosystem. This difference can be explained by the electrostatic interaction between NYS (negatively charged) and CS (positively charged), by which it can be inferred that the IONPs-CS-NYS nanosystem was able to generate a controlled release of NYS. Ketoconazole and amphotericin B are other antifungal drugs that have been tested in the development of magnetic nanosystems in order to decrease their side effects and improve antifungal action. Ketoconazole was coupled to epoxy-functionalized IONPs immobilized with HSA, and its binding mechanism occurred via hydrophobic interaction [197], while amphotericin B was directly bound to IONPs by a reaction between amine and aldehyde groups, respectively from the antifungal drug and IONPs [198].

\section{Antimicrobial Activity of IONPs-Based Nanosystems}

Studies suggest that the potential of magnetic nanoparticles to generate microbial toxicity is due to a series of interactions, including membrane depolarization with consequent impairment of cell integrity [199], production of reactive oxygen species (ROS) with lipid peroxidation and DNA damage [200], and release of metal ions that affect cellular homeostasis and protein coordination [201] (Figure 3).

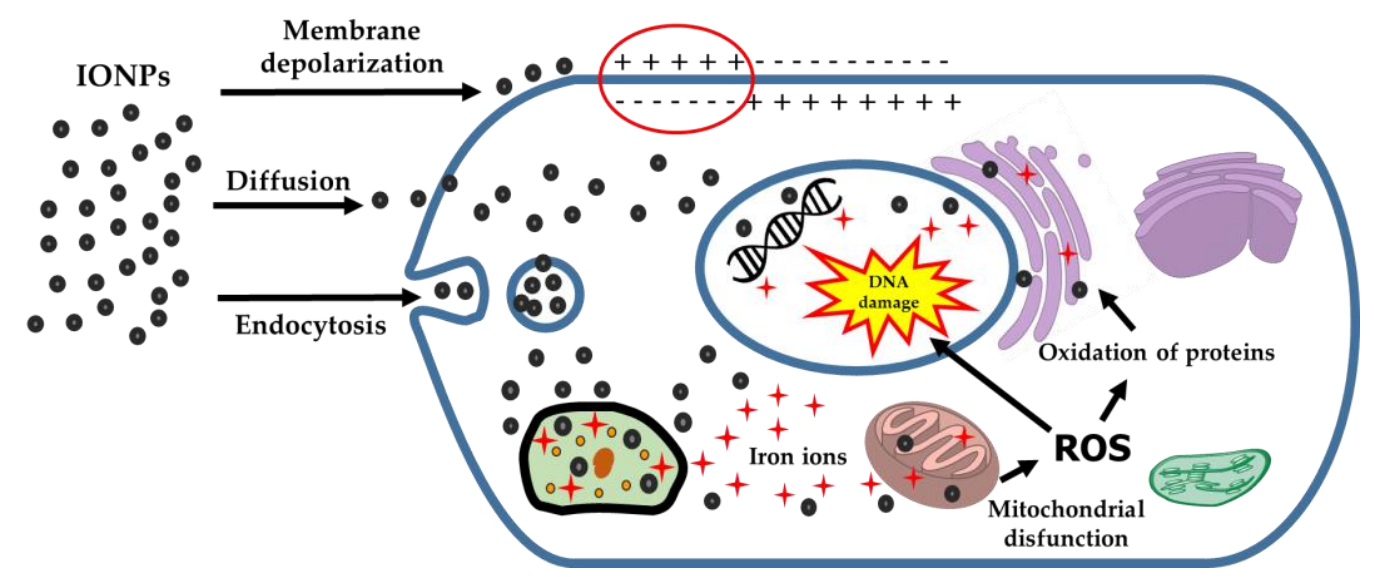

Figure 3. Main mechanisms of action by which systems based on iron oxide nanoparticles (IONPs) generate cell toxicity. ROS: reactive oxygen species. 
The antimicrobial potential of nanosystems has been evaluated against microorganisms in the planktonic state or forming biofilms, whose stage of development can affect the nanoparticles' activity. The minimum inhibitory concentration (MIC) of the IONPs-amoxicillin nanosystem on Staphylococcus aureus and Escherichia coli planktonic cells was shown to be 3 to 4 times lower than the antibiotic alone [202]. This nanosystem was also able to decrease the initial adhesion of those bacteria to polystyrene during the first $24 \mathrm{~h}$ of biofilm formation. In turn, the IONPs-CS-streptomycin nanosystem exhibited a more significant effect on Gram-negative microorganisms than on Gram-positive [189,190].

Aiming to potentiate antibiotics such as rifampicin, doxycyclin, ceftriaxone and cefotaxime, studies proposed their linking to $1.6 \%$ Ag-decorated IONPs [100,191]. While IONPs alone did not prevent the growth of Bacillus pumilus, small inhibition halos $(\leq 2 \mathrm{~mm})$ were observed for IONPs-Ag, IONPs-Ag-ceftriaxone and IONPs-Ag-cefotaxime nanosystems [100]. Furthermore, halos around $20 \mathrm{~mm}$ were found for IONPs-Ag-rifampicin and IONPs-Ag-doxycyclin [100]. For S. aureus, only the IONPs-Ag-rifampicin, IONPs-Ag-doxycycline and IONPs-Ag-ceftriaxone nanosystems were effective, producing inhibition halos ranging from 10 to $24 \mathrm{~mm}$ [191]. Furthermore, the IONPs-SI-Ag-vancomycin nanostructure was more effective than free vancomycin in inactivating strains of $E$. coli and methicillin-resistant S. aureus [203]. Differences in the employed antibiotic concentrations may help to explain the results obtained. Finally, higher silver concentrations (5-10\%) attached to IONPs and rifampicin were able to impair the growth of Streptococcus salivarius and S. aureus, but the same trend was not found for Pseudomonas fluorescens and B. pumilus, indicating that the effect of the nanocarrier is species-dependent. The increase in Ag concentration also improved the antibacterial properties against S. salivarius and S. aureus, amplifying the action spectrum of the antibiotic.

The incorporation of IONPs-based nanosystems into medical devices has shown promising results regarding the inhibition of microbial colonization. Catheter surfaces coated with essential oils-loaded IONPs decreased initial cell adhesion of S. aureus and Klebsiella pneumoniae, with a lesser effect on more mature stages of biofilm formation [178]. In turn, coating of textile fibers of wound dressings with patchouli essential oil-attached IONPs was effective in reducing the number of $S$. aureus biofilm cells [103]. Still concerning natural compounds, gallic acid-coated IONPs was shown to exhibit similar antimicrobial effects compared to ampicillin, streptomycin and nystatin against E. coli, Bacillus substilis and Aspergillus niger, respectively [204].

Despite the positive outcomes described above, conflicting results were reported for other nanosystems. While a nanosystem composed by IONPs, spray-dried lactose (SDL) and ciprofloxacin was shown to decrease the total biomass and metabolic activity of Pseudomonas aeruginosa biofilms (with an enhanced effect promoted by a magnetic field) [194], the IONPs-ciprofloxacin nanosystem did not exhibit antimicrobial effects against E. coli, P. aeruginosa, methicillin-sensitive S. aureus, methicillin-resistant S. aureus, Streptococcus pneumoniae, vancomycin-sensitive Enterococcus faecalis, vancomycin-resistant E. faecalis, Acinetobacter baumannii, Proteus mirabilis, K. pneumoniae, Streptococcus pyogenes, Haemophilus influenzae, Staphylococcus epidermidis, Enterobacter aerogenes, Citrobacter freundii, and Enterobacter cloacae tested in the planktonic state or forming biofilms [193]. Unfavorable results were also reported for P. aeruginosa, in which stimulation of biofilm formation was promoted by IONPs $[205,206]$.

Drug carriers have also been tested as alternatives to combat the resistance of oral biofilms to commercially available drugs. Chlorhexidine (CHX), an antimicrobial agent used to control oral biofilms, was shown to be more effective when bound to IONPs in reducing biofilm biomass of S. aureus, $E$. faecalis and Candida albicans, in comparison with the drug applied alone [207]. Moreover, CHX particles functionalized with IONPs inhibited the growth of Porphyromonas gingivalis and, when incorporated into HEMA-UDMA resin discs, revealed a CHX release kinetics influenced by magnetic field [208].

It is believed that nanoparticles have the ability to adsorb and penetrate into biofilms due to their physicochemical characteristics, such as surface charge, hydrophobicity and high surface area ratio by volume $[209,210]$. Positively charged and neutral IONPs promoted higher reduction of cells of Streptococus mutans biofilms with respect to negatively charged counterparts [211], highlighting the influence of the surface properties of magnetic nanoparticles on their antibiofilm activity. Furthermore, 
IONPs have a good performance as catalysts, being nominated as catalytic IONPs (IONPs-CAT) or nanozymes. IONPs-CAT in association with $\mathrm{H}_{2} \mathrm{O}_{2}$ showed an enhanced antimicrobial effect on S. mutans biofilms compared to its counterpart without $\mathrm{H}_{2} \mathrm{O}_{2}$ in vitro [212]. Under in vivo conditions, IONPs-CAT attenuated caries initiation and the severity of lesions, while $\mathrm{H}_{2} \mathrm{O}_{2}$ alone did not exhibit considerable effects [212], showing the potential of the IONPs in combating dental caries.

Besides drugs with antibacterial action, the association of IONPs with antifungal agents has shown to promote a significant effect on different microbial species. When amphotericin $B$ and NYS were coupled to IONPs, the antifungal effect of the resulting nanosystems was potentiated in comparison with the free drugs on Candida spp. [198]. In addition, CS-coated IONPs loaded with NYS promoted reductions of 1.3, 35.0, 99.0 and $99.9 \%$ in the number of cultivable cells of S. aureus, E. coli, P. aeruginosa and C. albicans, respectively, despite free NYS promoted a greater inhibition halo for C. albicans compared to the IONPs-CS-NYS nanosystem and the IONPs alone [196]. Miconazole (MCZ), another conventional antifungal agent used for the treatment of oral candidiasis, has also been incorporated in CS-coated IONPs (Figure 4A). This new nanosystem showed a higher ability in disrupting dual-species biofilms of C. albicans and C. glabrata (Figure 4D) with respect to MCZ alone in vitro (Figure $4 \mathrm{C}$ ), as evident by a less compact structure composed by a lower number of cell layers partially covering the surface (Figure 4D).
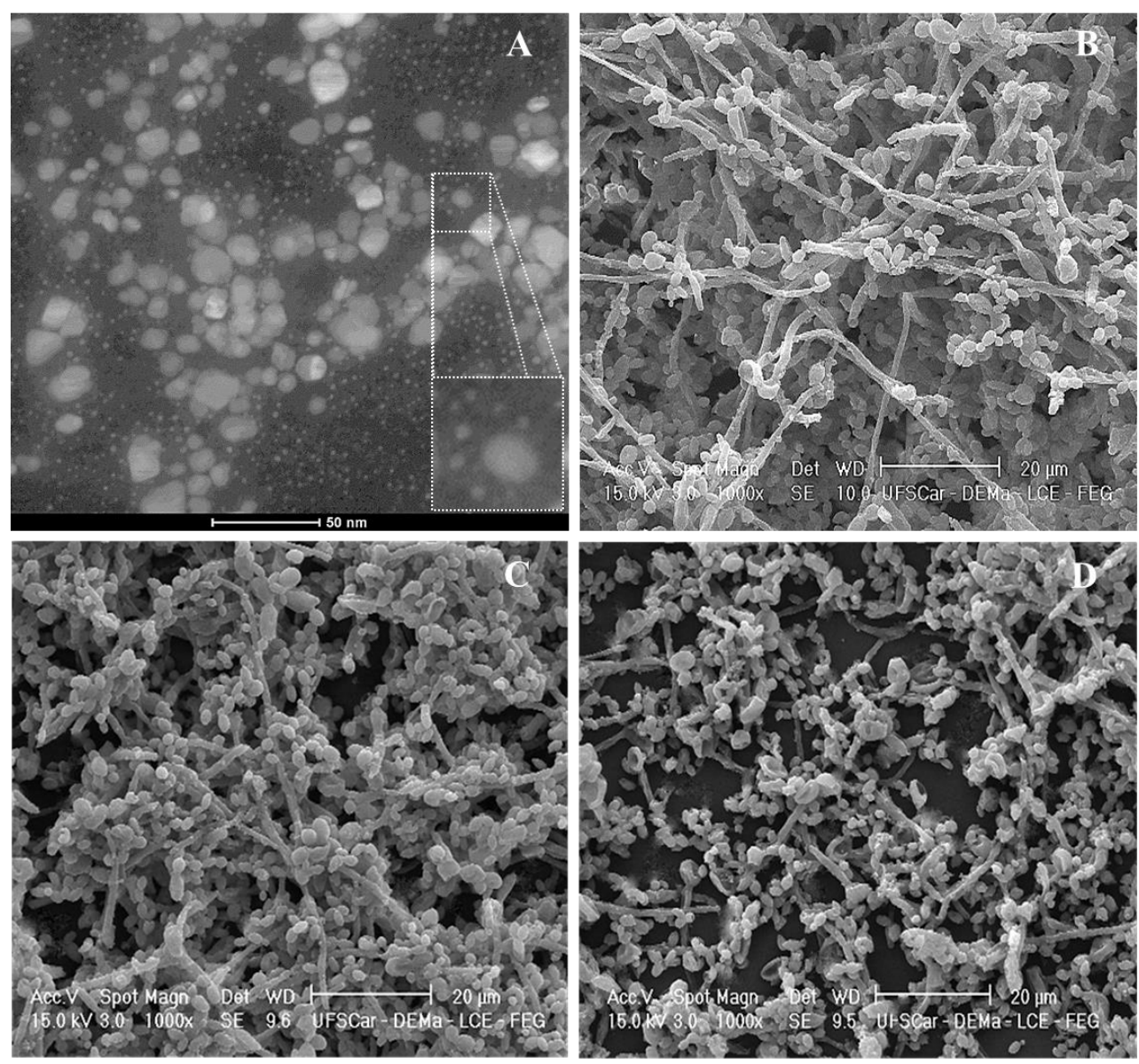

Figure 4. (A) Transmission electron microscopy image obtained from a miconazole (MCZ)-carrier nanosystem based on iron oxide nanoparticles (IONPs) and chitosan (CS); increased image at the bottom right corner shows the core of a CS-coated IONP, with MCZ particles adhered to CS; (B) Scanning electron microscopy (SEM) image of untreated dual-species biofilm of C. albicans and C. glabrata $(48 \mathrm{~h})$. SEM images of dual-species biofilms treated for $24 \mathrm{~h}$ with $78 \mu \mathrm{g} / \mathrm{mL} \mathrm{MCZ} \mathrm{(C)} \mathrm{or} \mathrm{MCZ-containing}$ nanosystem at $78 \mu \mathrm{g} / \mathrm{mL}$ (D). Source: the authors (unpublished data). 


\section{IONPs Toxicity}

Conflicting evidence regarding the toxicity of IONPs has been reported in in vitro and in vivo studies [213-216]. Factors inherent to nanosystems involving IONPs tend to directly interfere with their toxicity. For instance, changes in nanoparticle size and shape were shown to play an important role on cell toxicity, with rod-shaped or nano-sized IONPs being more toxic than sphere-shaped and micrometric particles, respectively [217]. The configuration of the nanosystem can also influence IONPs toxicity. A Janus microsphere encapsulating mesenchymal stem cells (MSC) and IONPs in two different compartments was proven to facilitate the magnetization and movement of the microspheres (due to the higher load capacity of IONPs), and to reduce cell toxicity, since the IONPs' derived toxic chemicals were isolated from the MSC compartment [107]. Furthermore, the surface charge of IONPs may affect cell cytotoxicity and genotoxicity. Positively charged IONPs were shown to be more toxic, since they undergo nonspecific interactions and adsorptive endocytosis with the negatively charged cell membrane, thus increasing their intracellular accumulation and affecting cell membrane integrity [218]. Other factors such as concentration, type of coating, form of administration, as well as the cell line may explain the different results for IONPs toxicity $[21-23,25,26,66,71,72,96-98,163,214,215,219-248]$, as shown in Table 1. 
Table 1. Summary of studies assessing the toxicity of iron oxide magnetic nanoparticles (IONPs) carried out between 2014 and 2018.

\begin{tabular}{|c|c|c|c|c|c|c|}
\hline Reference & Year & Coating & Concentration & Cell Line or in Vivo Model & Study Model & Toxicity \\
\hline [221] & 2014 & Manganese (Mn) & $\begin{array}{l}5,10,20,50 \text { and } 100 \mathrm{mg} / \mathrm{L} \\
\text { (in vitro); } 150 \mu \mathrm{mol} / \mathrm{kg} \\
\mathrm{Fe} / \mathrm{kg} \text { body weight (in vivo) }\end{array}$ & $\begin{array}{l}\text { Murine Balb / } 3 \mathrm{~T} 3 \text { fibroblasts (in vitro) and CD1 } \\
\text { female mice ( } 8 \text { weeks old) (in vivo) }\end{array}$ & In vitro/In vivo & Dose-dependent toxicity \\
\hline [222] & 2014 & $\begin{array}{l}\text { Poly(lactic-co-glycolic acid) (PLGA) + } \\
\text { 5-Fluorouracil }\end{array}$ & 50,100 and $200 \mu \mathrm{M}$ & Human prostate cancer cell line DU145 & In vitro & Non toxic \\
\hline [26] & 2014 & Silica shell $\left(\mathrm{Fe}_{3} \mathrm{O}_{4} / \mathrm{SiO}_{2} \mathrm{NPs}\right)$ & $0.5,1,2.5$ and $5 \mathrm{nM}$ & A549 and HeLa cells & In vitro & $\begin{array}{l}\text { Silica coating diminished } \\
\mathrm{Fe}_{3} \mathrm{O}_{4} \text { cytotoxic and } \\
\text { genotoxic effects }\end{array}$ \\
\hline [21] & 2014 & $\begin{array}{l}\text { Poly-(ethylene glycol) (PEG) } \\
\text { (PEGylated IONPs) }\end{array}$ & 100 and $500 \mathrm{ppm} \mathrm{Fe}$ & Bovine vascular smooth muscle cells (VSMCs) & In vitro & $\begin{array}{l}\text { PEGylated IONPs showed } \\
\text { less cytotoxicity than } \\
\text { uncoated IONPs }\end{array}$ \\
\hline [223] & 2014 & - & 1,3 and $5 \mathrm{mg} / \mathrm{mL}$ & $\begin{array}{l}\text { Epithelial cell and cancer cell lines; ECR } 116 \\
\text { (NCBI code: C570) }\end{array}$ & In vitro & Non toxic \\
\hline [224] & 2014 & $\begin{array}{c}\text { Aminodextran (AD), } \\
\text { 3-aminopropyltriethoxysilane (APS) } \\
\text { and dimercaptosuccinic acid (DMSA) }\end{array}$ & $0.05,0.1$, and $0.5 \mathrm{mg} / \mathrm{mL}$ & HeLa (human cervical adenocarcinoma) & In vitro & Non toxic \\
\hline [225] & 2015 & - & $214 \mathrm{mg} / \mathrm{L}$ & $\begin{array}{l}\text { Neuronal cell line (Rat } \\
\text { pheochromocytoma-PC12 cells) }\end{array}$ & In vitro & Neurocytotoxic \\
\hline [226] & 2015 & - & $25,50,75$ and $100 \mathrm{mg} / \mathrm{L}$ & Human hepatoma cells (Hep G2) & In vitro & $\begin{array}{l}\text { Toxic (reduced cell viability } \\
\text { with oxidative damage) }\end{array}$ \\
\hline [227] & 2015 & Polyhydroxybutyrate (PHB) & $29-500 \mu \mathrm{M}$ & $\begin{array}{l}\text { MCF-7, SKBR-3 and HeLa human breast and } \\
\text { ovarian cancer cell lines }\end{array}$ & In vitro & Non toxic \\
\hline [228] & 2015 & Curcumin (Cur) & $\begin{array}{l}\text { IONPs: } 120 \mathrm{mg} / \mathrm{L} \\
\text { Cur: } 40 \mathrm{mg} / \mathrm{L}\end{array}$ & $\begin{array}{l}\text { Wild type MDKC and human } \\
\text { neuroblastoma cells }\end{array}$ & In vitro & Non toxic \\
\hline [229] & 2015 & $\begin{array}{c}\text { L-DOPA } \\
\text { (L-3,4-dihydroxyphenylalanine) }\end{array}$ & $\begin{array}{l}0-0.05 \mathrm{mg} / \mathrm{mL} \text { (in vitro) and } \\
2.5 \mathrm{mg} / \mathrm{mouse} \\
\text { (approximately } 125 \mathrm{~g} / \mathrm{kg} \\
\text { body weight) (in vivo) }\end{array}$ & Normal mouse L929 fibroblasts/C57BL/6 mice & In vitro/in vivo & Non toxic \\
\hline [230] & 2015 & Polyacrylic acid (PAA) and non-coated & 4,20 and $100 \mathrm{mg} / \mathrm{L}$ & Human T lymphocytes & In vitro & Non genotoxic \\
\hline [231] & 2015 & - & $\begin{array}{l}200 \mathrm{and} 400 \mathrm{mg} / \mathrm{L} \text { (in vitro), } \\
\text { and } 200 \mathrm{mg} / \mathrm{L} \text { (in vivo) }\end{array}$ & $\begin{array}{l}\text { Mouse fibroblast cell (in vitro) and wistar rat's } \\
\text { liver and kidney (in vivo) }\end{array}$ & In vitro/In vivo & Non toxic \\
\hline [232] & 2015 & $\begin{array}{c}\text { Alginate (Alg)/Alg + D-galactosamine } \\
\text { (GA) }\end{array}$ & $0-1000 \mathrm{mg} / \mathrm{L}$ & $\begin{array}{l}\text { Liver cancer/hepatocellular carcinoma (HepG2) } \\
\text { cell line }\end{array}$ & In vitro & Non toxic \\
\hline [233] & 2015 & $\begin{array}{l}\text { Uncoated }\left(\mathrm{U}-\mathrm{Fe}_{3} \mathrm{O}_{4}\right) \text { and oleate-coated } \\
\qquad \mathrm{Fe}_{3} \mathrm{O}_{4}\left(\mathrm{OC}-\mathrm{Fe}_{3} \mathrm{O}_{4}\right)\end{array}$ & $10.8,21.6$ and $108 \mathrm{mg} / \mathrm{L}$ & $\begin{array}{l}\text { Human lymphoblastoid TK6 cells and primary } \\
\text { human blood cells }\end{array}$ & In vitro & $\begin{array}{l}\mathrm{U}-\mathrm{Fe}_{3} \mathrm{O}_{4} \text { was not toxic; } \\
\mathrm{OC} \mathrm{Fe}_{3} \mathrm{O}_{4} \text { was cytotoxic in } \\
\text { a dose-dependent manner } \\
\text { and genotoxic }\end{array}$ \\
\hline$[71]$ & 2015 & $\begin{array}{c}\text { Bare (uncoated) SPION (BS) and PEG } \\
\text { (PEG-SPION (PS)) }\end{array}$ & $\begin{array}{l}50.8 \mathrm{mg} / \mathrm{kg} \mathrm{b} \text { w for PS and } \\
16.3 \mathrm{mg} / \mathrm{kg} \mathrm{b} \mathrm{w} \text { for BS }\end{array}$ & BALB/c Swiss Albino mice & In vivo & $\begin{array}{l}\text { PEGylation reduced the } \\
\text { toxicity of BS (Low toxicity) }\end{array}$ \\
\hline [234] & 2015 & Cobalt & $\begin{array}{l}75,150,250,500,750 \text { and } \\
1,000 \mathrm{mg} / \mathrm{L}\end{array}$ & MCF-7 cell lines & In vitro & $\begin{array}{l}\text { Moderate toxicity to } \\
\text { cancer cells }\end{array}$ \\
\hline
\end{tabular}


Table 1. Cont.

\begin{tabular}{|c|c|c|c|c|c|c|}
\hline Reference & Year & Coating & Concentration & Cell Line or in Vivo Model & Study Model & Toxicity \\
\hline [235] & 2016 & Rhamnose & $\begin{array}{l}0,1,2,5,10,25,50 \text { and } 100 \mu \mathrm{g} \\
\text { Fe } \mathrm{mL}^{-1} \text { for cancer cell lines, } \\
\text { and } 15.63 \text { to } 1000 \mu \mathrm{gFemL} L^{-1} \\
\text { for fibroblasts cell lines }\end{array}$ & $\begin{array}{l}\text { Human glioblastoma cell lines (T98G and } \\
\text { U251MG) and the human urinary bladder } \\
\text { carcinoma cell line (ECV304), mouse fibroblast } \\
\text { (BALB/3T3) cell line and its clone (A31-1-1). }\end{array}$ & In vitro & $\begin{array}{l}\text { Moderate toxicity to } \\
\text { tumoral cell lines and non } \\
\text { toxic to fibroblast cells }\end{array}$ \\
\hline [96] & 2016 & Silica and oleic acid & $5-300 \mathrm{mg} / \mathrm{L}$ & $\begin{array}{l}\text { Human neuroblastoma SHSY5Y and } \\
\text { glioblastoma A172 }\end{array}$ & In vitro & $\begin{array}{l}\text { Low citotoxicity/oleic } \\
\text { acid-coated IONPs with } \\
\text { less citotoxicity than } \\
\text { silica-coated IONPs }\end{array}$ \\
\hline [163] & 2016 & Mitoxantrone (MTO) & $0.0001-0.1 \mathrm{mg} / \mathrm{L}$ & Human primary tubular epithelial cells (hTEC) & In vitro & $\begin{array}{l}\text { Moderate toxicity (depends } \\
\text { on the drug loaded to the } \\
\text { SPION) }\end{array}$ \\
\hline [25] & 2016 & 2,3-dimercaptosuccinic acid (DMSA) & 15, 30, 60 e 80 mg/L (IONPs) & $\begin{array}{l}\text { human mesenchymal stem cells from dental } \\
\text { pulp tissues }\end{array}$ & In vitro & Non toxic \\
\hline [236] & 2016 & No coating and curcumin-coating & $1-1000 \mathrm{mg} / \mathrm{L}$ & $\begin{array}{l}\text { Human umbilical vein endothelial cells } \\
\text { (HUVECs) }\end{array}$ & In vitro & $\begin{array}{l}\text { Curcumin-coated IONPS } \\
\text { were less toxic than } \\
\text { uncoated IONPs }\end{array}$ \\
\hline [237] & 2016 & $\begin{array}{l}\text { Polyacrylic acid-co-maleic acid (PAM) } \\
+ \text { tissue plasminogen activator (tPA) }\end{array}$ & $30 \mu \mathrm{g} \mathrm{Fe} / \mathrm{mL}$ & $\begin{array}{l}\text { Human umbilical vein endothelial cells } \\
\text { (HUVECs) }\end{array}$ & In vitro & Low toxicity \\
\hline [238] & 2016 & $\begin{array}{c}\text { Polymer (converted from } \\
\text { Poly(lactic-co-glycolic acid) } \\
\text { nanoparticles) }\end{array}$ & $0.005-0.32 \mathrm{mg} / \mathrm{mL}$ & $\begin{array}{l}\text { SKOV3 human ovarian cancer cells and } \\
\text { NIH/3T3 murine fibroblasts }\end{array}$ & In vitro & Low toxicity \\
\hline [22] & 2016 & Chitosan + Gemcitabine & $\begin{array}{l}\text { IC } 50 \text { for SKBR-3 }(4.8 \mu \mathrm{M}) \text { and } \\
\text { MCF-7 }(1.5 \mu \mathrm{M})\end{array}$ & SKBR-3 and MCF-7 breast cancer cells & In vitro & $\begin{array}{l}\text { More cytotoxic to the tested } \\
\text { breast cancer cell lines than } \\
\text { free gemcitabine }\end{array}$ \\
\hline [239] & 2016 & - & $10,25,50,75$, and $100 \mathrm{mg} / \mathrm{L}$ & Human peripheral lymphocytes & In vitro & Moderate toxicity \\
\hline [215] & 2016 & - & $0-1000 \mathrm{mg} / \mathrm{L}$ & Human whole blood cultures & In vitro & Dose-dependent toxicity \\
\hline [240] & 2016 & - & $\begin{array}{l}65 \mathrm{ng} / \mathrm{mL} \text { (in vitro), and } 520 \\
\mu_{\mathrm{g} \mathrm{Fe}} \mathrm{Fe}_{4} / \mathrm{kg} \text { and } 20.8 \mu \mathrm{g} \\
\mathrm{Fe}_{3} \mathrm{O}_{4} / \mathrm{kg} \text { (in vivo) }\end{array}$ & $\begin{array}{l}\text { Mouse embryonic fibroblasts NIH3T3 (in vitro) } \\
\text { and Wistar rats (in vivo) }\end{array}$ & In vitro/In vivo & $\begin{array}{l}\text { Non toxic at a desirable } \\
\text { concentration }\end{array}$ \\
\hline [23] & 2016 & PEG350 and PEG2000 & $\begin{array}{l}50-200 \mathrm{mg} / \mathrm{L} \text { (in vitro) } / 12.5 \\
25 \text { and } 50 \mathrm{mg} / \mathrm{kg} / \text { day } \\
\text { (in vivo) }\end{array}$ & $\begin{array}{l}\text { Monkey kidney ephitelium (Vero), dog kidney } \\
\text { fibroblasts (MDKC) and mouse embryonic } \\
\text { fibroblast (NIH-3 T3) (in vitro) and Swiss albino } \\
\text { male mice (in vivo) }\end{array}$ & In vitro/In vivo & $\begin{array}{l}\text { SPION-PEG2000 showed } \\
\text { no toxicity in vitro, but } \\
\text { lead to liver and kidney } \\
\text { injury in vivo. In vitro, } \\
\text { SPION-PEG350 showed no } \\
\text { toxicity up to } 100 \mathrm{\mu g} / \mathrm{mL}\end{array}$ \\
\hline [241] & 2016 & $c($ RGDyK $)+$ dopamine & $\begin{array}{l}1.50,2.07,2.87,3.97,5.49,7.59 \\
\text { and } 8.50 \mathrm{~g} / \mathrm{kg}\end{array}$ & Kunming mice of SPF grade & In vivo & Non toxic \\
\hline [242] & 2017 & $\begin{array}{l}\text { Poly-(ethylene glycol) (PEG) and } \\
\text { polyethylenimine (PEI) polymers + } \\
\text { folic acid (FA-IONPs) } \\
\text { Doxorubicin + FA IONPs } \\
\text { (DOX@FA-IONPs) }\end{array}$ & $0.2-10 \mathrm{mg} / \mathrm{L}$ & MCF7 cells & In vitro & $\begin{array}{l}\text { FA-IONPs show low } \\
\text { cytotoxicity and } \\
\text { DOX@FA-IONPs is more } \\
\text { cytotoxic than free DOX }\end{array}$ \\
\hline
\end{tabular}


Table 1. Cont

\begin{tabular}{|c|c|c|c|c|c|c|}
\hline Reference & Year & Coating & Concentration & Cell Line or in Vivo Model & Study Model & Toxicity \\
\hline [243] & 2017 & $\begin{array}{l}\text { Tri-block copolymer: } \\
\text { poly( } \varepsilon \text {-caprolactone)-poly(ethylene } \\
\text { glycol)-poly( } \varepsilon \text {-caprolactone) } \\
\text { (PCL-PEG-PCL, PCEC) }\end{array}$ & $0,0.5,1,2,5$ and $10 \%$ & $\mathrm{NIH} 3 \mathrm{~T} 3$ cells & In vitro & $\begin{array}{l}\text { The PCEC coating reduced } \\
\mathrm{Fe}_{3} \mathrm{O}_{4} \mathrm{NPs} \text { toxicity }\end{array}$ \\
\hline [97] & 2017 & $\begin{array}{c}\mathrm{SiO}_{2}\left(\mathrm{Fe}_{\mathrm{m}} \mathrm{O}_{\mathrm{n}}-\mathrm{SiO}_{2} \text { composite and }\right. \\
\mathrm{SiO}_{2}-\mathrm{Fe}_{\mathrm{m}} \mathrm{O}_{\mathrm{n}} \text { core-shell IONPs) }\end{array}$ & $0.7,7.0$ and $70.0 \mu \mathrm{g}$ & $\begin{array}{l}\text { Human umbilical vein endothelial cell culture } \\
\text { (cultured HUVECs) }\end{array}$ & In vitro & $\begin{array}{l}\text { Dose-dependent toxicity in } \\
\text { the presence of silica. Bare } \\
\text { IONPs were less toxic }\end{array}$ \\
\hline [244] & 2017 & $\begin{array}{l}\text { Chitosan (CS) + calf-thymus DNA } \\
\text { (DNA) }\end{array}$ & - & Human foreskin fibroblast cell line (HFFF2) & In vitro & Non toxic \\
\hline [245] & 2017 & Zinc/Cobalt & $10,100,250$ and $500 \mu \mathrm{M}$ & $\begin{array}{l}\text { Primary human bone marrow-derived } \\
\text { mesenchymal stem cells (hMSCs) and human } \\
\text { osteosarcoma-derived cells (MG-63) }\end{array}$ & In vitro & $\begin{array}{l}\text { The levels of toxicity do not } \\
\text { compromise the } \\
\text { biocompatibility }\end{array}$ \\
\hline [246] & 2017 & - & $\begin{array}{l}10,25,50,100, \text { and } 200 \\
\mathrm{mg} / \mathrm{mL}(0.3 \mathrm{~mL} / \mathrm{egg} \text { in } \\
\text { airspace) }\end{array}$ & $\begin{array}{l}\text { Fertilized eggs of White leghorn (Gallus gallus } \\
\text { domesticus) }\end{array}$ & In vivo & $\begin{array}{l}\text { Neurotoxic in lower doses } \\
\text { and } 100 \% \text { mortality at } 200 \\
\mathrm{mg} / \mathrm{mL} \text { dose }\end{array}$ \\
\hline [72] & 2017 & Polyvinylpirrolidone & $1,10,25,50$ and $100 \mu \mathrm{g} / \mathrm{mL}$ & Human neuroblastoma (SH-SY5Y cell line) & In vitro & Dose-dependent toxicity \\
\hline [98] & 2018 & $\begin{array}{c}\text { Luminescent ruthenium (II) complex } \\
\text { encapsulated with silica shell + amine } \\
\text { group } \\
\text { (APTMS)-Fe } \mathrm{F}_{3} \mathrm{O}_{4} @ \mathrm{SiO}_{2} @\left[\mathrm{Ru}(\mathrm{Phen})_{3}\right] \\
2+\mathrm{SiO}_{2} @ \mathrm{NH}_{2}\end{array}$ & 10,50 and $100 \mu \mathrm{g} / \mathrm{mL}$ & Cancer cell (B16F10) and normal cell (CHO) & In vitro & Low cytotoxicity \\
\hline [66] & 2018 & - & $\begin{array}{l}0.1,0.5,1,2.5,5 \text { and } 7.5 \\
\mathrm{mg} / \mathrm{mL}\end{array}$ & MCF7 and 3T3 cell lines & In vitro & Dose-dependent toxicity \\
\hline [219] & 2018 & $\begin{array}{l}\text { Polyethylenimine (PEI) and } \\
\text { polyethylene glycol (PEG) }\end{array}$ & $\begin{array}{l}3.125-100 \mu \mathrm{g} / \mathrm{mL} \\
\text { (in vitro) } / \mathrm{Up} \text { to } 5 \mathrm{mg} / \mathrm{kg} \\
\text { (in vivo) }\end{array}$ & $\begin{array}{l}\text { RAW2 } 64.7 \text { macrophages and non-phagocytic } \\
\text { SKOV-3 ovarian cancer cells (in vitro)/SKOV-3 } \\
\text { tumor bearing nude mice and BALB/c mice } \\
\text { (in vivo) }\end{array}$ & In vitro/In vivo & $\begin{array}{l}\text { PEI-coated-IONPs were } \\
\text { toxic in vitro with } \\
\text { dose-dependent toxicity } \\
\text { in vivo/PEG-coated-IONPs } \\
\text { presented low toxicity }\end{array}$ \\
\hline [247] & 2018 & $\begin{array}{l}\text { Polyamidoamine (PAMAM) } \\
\text { dendrimer (Fourth generation }-\mathrm{G}_{4} \text { ) }\end{array}$ & $\begin{array}{l}\text { Acute toxicity: } 25,50 \text { and } 100 \\
\mathrm{mg} / \mathrm{kg} \text { Chronic toxicity: } 0.5,1, \\
5 \mathrm{and} 10 \mathrm{mg} / \mathrm{Kg}\end{array}$ & $\mathrm{BALB} / \mathrm{c}$ mice & In vivo & Acceptable toxicity \\
\hline [248] & 2018 & Chitosan (CS)-dextran (DX) & $1,5,10,50$, and $150 \mu \mathrm{g} / \mathrm{mL}$ & $\begin{array}{l}\text { Rat C6 glioma, human U87 glioma, and human } \\
\text { cervix carcinoma HeLa cells }\end{array}$ & In vitro & $\begin{array}{l}\text { Dose and time-dependent } \\
\text { toxicity }\end{array}$ \\
\hline
\end{tabular}




\subsection{Mechanisms of IONPs Toxicity}

The toxicity of IONPs for different cell lines may be partially explained by the production of ROS, which causes cellular oxidative stress [249]. When uptaken by cells via endocytosis, IONPs tend to accumulate in the lysosomes and are degraded in iron ions (Figure 3). In theory, the ions could cross the membranes and reach regions such as the cell nucleus and mitochondria, reacting with hydrogen peroxide and oxygen, thus generating ROS [250,251] (Figure 3).

Despite oxidative stress is the most well-studied hypothesis of toxicity and cell damage, iron overload caused by exposure to IONPs can also generate serious deleterious effects and lead to cell death $[246,250,251]$. On the other hand, magnetite was shown to be responsible for increasing the level of lipid peroxidation and decreasing antioxidant enzymes of human lung alveolar epithelial cells (A-549), displaying a concentration-dependent toxicity in vitro [252]. In addition, a high dose of IONPs (with consequent iron excess) promoted elevated lipid metabolism, breakage of iron homeostasis and exacerbated loss of liver functions, being considered a risk factor for cirrhosis in a mice-model study [253].

\subsection{Influence of Coatings on IONPs Toxicity}

The surface coating of IONPs is a widely used procedure in order to make these nanoparticles biocompatible and non-toxic, supposedly due to lower number of oxidative sites, with consequent less DNA damage [254]. In this sense, a well referenced in vitro study showed that uncoated IONPs produced greater toxicity for rat fibroblast cells when compared to nanoparticles coated with polyvinyl alcohol, due to changes in the protein functions and cellular ion balance caused by gas vesicles after exposure to uncoated particles [255]. Additionally, uncoated IONPs were shown to increase intracellular density (greater ROS production), which might lead to relevant morphological cellular alterations, whereas protein-coated IONPs reached densities capable of causing tolerable changes [256]. Also, the use of lauric acid, protein corona of BSA, or dextran as shells for IONPs did not promote genotoxic effects on human granulosa cells [257].

Coating with polymers and essential oils can also reduce the toxic effects of IONPs. PLGA-functionalized IONPs were able to reduce the destructive effects on lysosomes, mitochondria, golgi body and endoplasmic reticulum compared with uncoated nanoparticles, which induced the cells to autophagy [258]. In turn, IONPs functionalized with patchouli essential oil promoted low cytotoxicity on mammalian cells and good biodistribution after intraperitoneal injection in mice [103].

Despite the remarkable advantages of IONPs coating, some divergences have been reported in the literature. Previous data showed that the coating of IONPs with D-mannose or poly-l-lysine was not able to prevent their toxicity in murine neural stem cells, as these nanoparticles demonstrated negative effects on the mithocondrial homeostasis [259]. This emphasizes the importance of conducting additional tests other than cell viability for a more complete assessment of the toxic effects of these nanosystems.

\section{Conclusions and Perspectives}

Microorganisms resistant to conventional treatments evolve faster than the creation of new drugs and antibiotics. Within this context, IONPs bear great potential for use in nanosystems capable of overcoming the physical barriers of the microbial biofilm matrix in delivering the drugs directly to the target. The next steps consist in further exploring the magnetic properties of IONPs to improve the drug effect using lower concentrations, thus reducing side effects and toxicity.

The various methods of synthesis have allowed the creation of nanoparticles with different sizes, structures, dispersions and surface modifications. However, as wide variations have been reported among different research protocols, a direct comparison of the results obtained cannot be done. This aspect points out to the need for a refinement/standardization of protocols of synthesis 
and functionalization prior to in vivo testing, aiming to produce nanoparticles with adequate stability, size-control, biocompatibility and bioavailability.

Despite the growing body of scientific evidence on the use of IONPs in drug delivery systems, not all relevant drugs of medical/dental interest have been investigated, either alone or in combination with IONPs. In this sense, the conception of novel IONPs-based nanosystems able to carry multiple drugs simultaneously, and with adequate release control on the target tissues could be beneficial in several clinical situations. These include the prevention/control of diseases associated with multiple microorganisms (e.g., bacteria and fungi), as well as conditions that require different categories of drugs (e.g., anti-inflammatories, antibiotics and antifungals).

Finally, regarding the applicability of IONPs-based nanosystems, most of clinical trials conducted so far have focused on MRI, so that clinical assessment of applications other than MRI is expected in the near future. For such purpose, large and industrial-scale production of IONPs-based nanosystems is an important challenge to be overcome.

Author Contributions: Study was conceived and designed by D.R.M., J.P.P. and A.C.B.D.; review was performed by L.S.A., A.P.M.V. and T.M.T.d.L.; results were critically analyzed by D.R.M., J.P.P., A.C.B.D., L.S.A., A.P.M.V. and T.M.T.d.L.; manuscript was drafted and revised by D.R.M., J.P.P., A.C.B.D., L.S.A., A.P.M.V. and T.M.T.d.L.

Funding: This research received no external funding.

Acknowledgments: The authors thank Francisco Nunes de Souza Neto for TEM and SEM analysis, and Bruno Henrique Ramos de Lima and $n$ Chemi Company (São Carlos, SP, Brazil) for providing the colloidal suspensions of IONPs used in Figure 4.

Conflicts of Interest: The authors declare no conflict of interest.

\section{References}

1. Riviere, C.; Roux, S.; Tillement, O.; Billotey, C.; Perriat, P. Nano-systems for medical applications: Biological detection, drug delivery, diagnostic and therapy. Ann. Chim. Sci. Mater. 2006, 31, 351-367. [CrossRef]

2. Suri, S.S.; Fenniri, H.; Singh, B. Nanotechnology-based drug delivery systems. J. Occup. Med. Toxicol. 2007, 2, 16. [CrossRef] [PubMed]

3. Ochekpe, N.A.; Olorunfemi, P.O.; Ngwuluka, N.C. Nanotechnology and drug delivery part 1: Background and applications. Trop. J. Pharm. Res. 2009, 8, 265-274. [CrossRef]

4. Niemirowicz, K.; Markiewicz, K.H.; Wilczewska, A.Z.; Car, H. Magnetic nanoparticles as new diagnostic tools in medicine. Adv. Med. Sci. 2012, 57, 196-207. [CrossRef] [PubMed]

5. Wilczewska, A.Z.; Niemirowicz, K.; Markiewicz, K.H.; Car, H. Nanoparticles as drug delivery systems. Pharmacol. Rep. 2012, 64, 1020-1037. [CrossRef]

6. Mashhadi Malekzadeh, A.; Ramazani, A.; Tabatabaei Rezaei, S.J.; Niknejad, H. Design and construction of multifunctional hyperbranched polymers coated magnetite nanoparticles for both targeting magnetic resonance imaging and cancer therapy. J. Colloid Interface Sci. 2017, 490, 64-73. [CrossRef] [PubMed]

7. $\mathrm{Gu}, \mathrm{H} . ; \mathrm{Xu}, \mathrm{K} . ; \mathrm{Xu}, \mathrm{C} . ; \mathrm{Xu}$, B. Biofunctional magnetic nanoparticles for protein separation and pathogen detection. Chem. Commun. 2006, 941-949. [CrossRef] [PubMed]

8. Lin, R.; Li, Y.; MacDonald, T.; Wu, H.; Provenzale, J.; Peng, X.; Huang, J.; Wang, L.; Wang, A.Y.; Yang, J.; et al. Improving sensitivity and specificity of capturing and detecting targeted cancer cells with anti-biofouling polymer coated magnetic iron oxide nanoparticles. Colloids Surf. B Biointerfaces 2017, 150, 261-270. [CrossRef] [PubMed]

9. Zhang, Z.Q.; Song, S.C. Thermosensitive/superparamagnetic iron oxide nanoparticle-loaded nanocapsule hydrogels for multiple cancer hyperthermia. Biomaterials 2016, 106, 13-23. [CrossRef] [PubMed]

10. Saikia, C.; Das, M.K.; Ramteke, A.; Maji, T.K. Effect of crosslinker on drug delivery properties of curcumin loaded starch coated iron oxide nanoparticles. Int. J. Biol. Macromol. 2016, 93, 1121-1132. [CrossRef] [PubMed]

11. Lu, A.H.; Salabas, E.L.; Schüth, F. Magnetic nanoparticles: Synthesis, protection, functionalization, and application. Angew. Chem. Int. Ed. Engl. 2007, 46, 1222-1244. [CrossRef] [PubMed]

12. Rümenapp, C.; Gleich, B.; Haase, A. Magnetic nanoparticles in magnetic resonance imaging and diagnostics. Pharm. Res. 2012, 29, 1165-1179. [CrossRef] [PubMed] 
13. Anselmo, A.C.; Mitragotri, S. A review of clinical translation of inorganic nanoparticles. AAPS J. 2015, 17, 1041-1054. [CrossRef] [PubMed]

14. Clinicaltrials.gov. Available online: https://www.clinicaltrials.gov/ct $2 /$ results?term=iron + oxide+ nanoparticles (accessed on 7 May 2018).

15. Alam, S.R.; Shah, A.S.; Richards, J.; Lang, N.N.; Barnes, G.; Joshi, N.; MacGillivray, T.; McKillop, G.; Mirsadraee, S.; Payne, J.; et al. Ultrasmall superparamagnetic particles of iron oxide in patients with acute myocardial infarction: Early clinical experience. Circ. Cardiovasc. Imaging 2012, 5, 559-565. [CrossRef] [PubMed]

16. Raghunath, A.; Perumal, E. Metal oxide nanoparticles as antimicrobial agents: A promise for the future. Int. J. Antimicrob. Agents 2017, 49, 137-152. [CrossRef] [PubMed]

17. Mahmoudi, M.; Sant, S.; Wang, B.; Laurent, S.; Sen, T. Superparamagnetic iron oxide nanoparticles (SPIONs): Development, surface modification and applications in chemotherapy. Adv. Drug Deliv. Rev. 2011, 63, $24-46$. [CrossRef] [PubMed]

18. Assa, F.; Jafarizadeh-Malmiri, H.; Ajamein, H.; Anarjan, N.; Vaghari, H.; Sayyar, Z.; Berenjian, A. A biotechnological perspective on the application of iron oxide nanoparticles. Nano Res. 2016, 9, 2203-2225. [CrossRef]

19. Banerjee, T.; Mitra, S.; Kumar Singh, A.; Kumar Sharma, R.; Maitra, A. Preparation, characterization and biodistribution of ultrafine chitosan nanoparticles. Int. J. Pharm. 2002, 243, 93-105. [CrossRef]

20. Moghimi, S.M.; Hunter, A.C.; Murray, J.C. Long-circulating and target-specific nanoparticles: Theory to practice. Pharm. Rev. 2001, 52, 283-318.

21. Park, Y.C.; Smith, J.B.; Pham, T.; Whitaker, R.D.; Sucato, C.A.; Hamilton, J.A.; Bartolak-Suki, E.; Wong, J.Y. Effect of PEG molecular weight on stability, $\mathrm{T}_{2}$ contrast, cytotoxicity, and cellular uptake of superparamagnetic iron oxide nanoparticles (SPIONs). Colloids Surf. B Biointerfaces 2014, 119, 106-114. [CrossRef] [PubMed]

22. Parsian, M.; Unsoy, G.; Mutlu, P.; Yalcin, S.; Tezcaner, A.; Gunduz, U. Loading of Gemcitabine on chitosan magnetic nanoparticles increases the anti-cancer efficacy of the drug. Eur. J. Pharmacol. 2016, 784, 121-128. [CrossRef] [PubMed]

23. Silva, A.H.; Lima, E., Jr.; Mansilla, M.V.; Zysler, R.D.; Troiani, H.; Pisciotti, M.L.; Locatelli, C.; Benech, J.C.; Oddone, N.; Zoldan, V.C.; et al. Superparamagnetic iron-oxide nanoparticles mPEG350- and mPEG2000-coated: Cell uptake and biocompatibility evaluation. Nanomedicine 2016, 12, 909-919. [CrossRef] [PubMed]

24. Luchini, A.; Heenan, R.K.; Paduano, L.; Vitiello, G. Functionalized SPIONs: The surfactant nature modulates the self-assembly and cluster formation. Phys. Chem. Chem. Phys. 2016, 18, 18441-18449. [CrossRef] [PubMed]

25. Silva, L.H.; da Silva, J.R.; Ferreira, G.A.; Silva, R.C.; Lima, E.C.; Azevedo, R.B.; Oliveira, D.M. Labeling mesenchymal cells with DMSA-coated gold and iron oxide nanoparticles: Assessment of biocompatibility and potential applications. J. Nanobiotechnol. 2016, 14, 59. [CrossRef] [PubMed]

26. Malvindi, M.A.; De Matteis, V.; Galeone, A.; Brunetti, V.; Anyfantis, G.C.; Athanassiou, A.; Cingolani, R.; Pompa, P.P. Toxicity assessment of silica coated iron oxide nanoparticles and biocompatibility improvement by surface engineering. PLoS ONE 2014, 9, e85835. [CrossRef] [PubMed]

27. Zheng, X.C.; Ren, W.; Zhang, S.; Zhong, T.; Duan, X.C.; Yin, Y.F.; Xu, M.Q.; Hao, Y.L.; Li, Z.T.; Li, H.; et al. The theranostic efficiency of tumor-specific, $\mathrm{pH}$-responsive, peptide-modified, liposome-containing paclitaxel and superparamagnetic iron oxide nanoparticles. Int. J. Nanomed. 2018, 13, 1495-1504. [CrossRef] [PubMed]

28. Wu, W.; He, Q.G.; Jiang, C.Z. Magnetic iron oxide nanoparticles: Synthesis and surface functionalization strategies. Nanoscale Res. Lett. 2008, 3, 397-415. [CrossRef] [PubMed]

29. Wu, W.; Wu, Z.; Yu, T.; Jiang, C.; Kim, W.S. Recent progress on magnetic iron oxide nanoparticles: Synthesis, surface functional strategies and biomedical applications. Sci. Technol. Adv. Mater. 2015, 16, 023501. [CrossRef] [PubMed]

30. Huang, K.S.; Shieh, D.B.; Yeh, C.S.; Wu, P.C.; Cheng, F.Y. Antimicrobial applications of water-dispersible magnetic nanoparticles in biomedicine. Curr. Med. Chem. 2014, 21, 3312-3322. [CrossRef] [PubMed]

31. Lin, M.M.; Kim, D.K.; El Haj, A.J.; Dobson, J. Development of superparamagnetic iron oxide nanoparticles (SPIONS) for translation to clinical applications. IEEE Trans. Nanobiosci. 2008, 7, 298-305. [CrossRef] 
32. Kansara, K.; Patel, P.; Shukla, R.K.; Pandya, A.; Shanker, R.; Kumar, A.; Dhawan, A. Synthesis of biocompatible iron oxide nanoparticles as a drug delivery vehicle. Int. J. Nanomed. 2018, 13, 79-82. [CrossRef] [PubMed]

33. Drmota, A.; Drofenik, M.; Koselj, J.; Žnidaršič, A. Microemulsion method for synthesis of magnetic oxide nanoparticles. In Microemulsions-An Introduction to Properties and Applications, 1st ed.; Najjar, R., Ed.; InTech: Rijeka, Croatia, 2012; pp. 191-215. ISBN 978-953-51-0247-2.

34. Levy, L.; Sahoo, Y.; Kim, K.S.; Bergey, E.J.; Prasad, P.N. Nanochemistry: Synthesis and characterization of multifunctional nanoclinics for biological applications. Chem. Mater. 2002, 14, 3715-3721. [CrossRef]

35. Unsoy, G.; Gunduz, U.; Oprea, O.; Ficai, D.; Sonmez, M.; Radulescu, M.; Alexie, M.; Ficai, A. Magnetite: From synthesis to applications. Curr. Top. Med. Chem. 2015, 15, 1622-1640. [CrossRef] [PubMed]

36. Wu, S.; Sun, A.; Zhai, F.; Wang, J.; Xu, W.; Zhang, Q.; Volinsky, A.A. $\mathrm{Fe}_{3} \mathrm{O}_{4}$ magnetic nanoparticles synthesis from tailings by ultrasonic chemical co-precipitation. Mater. Lett. 2011, 65, 1882-1884. [CrossRef]

37. Liu, Y.; Jia, S.; Wu, Q.; Ran, J.; Zhang, W.; Wu, S. Studies of $\mathrm{Fe}_{3} \mathrm{O}_{4}$-chitosan nanoparticles prepared by co-precipitation under the magnetic field for lipase immobilization. Catal. Commun. 2011, 12, 717-720. [CrossRef]

38. Pereira, C.; Pereira, A.M.; Fernandes, C.; Rocha, M.; Mendes, R.; Fernández-García, M.P.; Guedes, A.; Tavares, P.B.; Grenèche, J.M.; Araújo, J.P.; et al. Superparamagnetic $\mathrm{MFe}_{2} \mathrm{O}_{4}(\mathrm{M}=\mathrm{Fe}, \mathrm{Co}, \mathrm{Mn})$ nanoparticles: Tuning the particle size and magnetic properties through a novel one-step coprecipitation route. Chem. Mater. 2012, 24, 1496-1504. [CrossRef]

39. Riaz, S.; Bashir, M.; Naseem, S. Iron oxide nanoparticles prepared by modified co-precipitation method. IEEE Trans. Magn. 2014, 50, 1-4. [CrossRef]

40. Yan, A.; Liu, Y.; Liu, Y.; Li, X.; Lei, Z.; Liu, P. A NaAc-assisted large-scale coprecipitation synthesis and microwave absorption efficiency of $\mathrm{Fe}_{3} \mathrm{O}_{4}$ nanowires. Mater. Lett. 2012, 68, 402-405. [CrossRef]

41. Wongwailikhit, K.; Horwongsakul, S. The preparation of iron (III) oxide nanoparticles using W/O microemulsion. Mater. Lett. 2011, 65, 2820-2822. [CrossRef]

42. Malik, M.A.; Wani, M.Y.; Hashim, M.A. Microemulsion method: A novel route to synthesize organic and inorganic nanomaterials. Arab. J. Chem. 2012, 5, 397-417. [CrossRef]

43. Deng, Y.; Wang, L.; Yang, W.; Fu, S.; Elaïssari, A. Preparation of magnetic polymeric particles via inverse microemulsion polymerization process. J. Magn. Magn. Mater. 2003, 257, 69-78. [CrossRef]

44. Kaur, G.; Dogra, V.; Kumar, R.; Kumar, S.; Singh, K. Fabrication of iron oxide nanocolloids using metallosurfactant-based microemulsions: Antioxidant activity, cellular, and genotoxicity toward Vitis vinifera. J. Biomol. Struct. Dyn. 2018, 27, 1-18. [CrossRef] [PubMed]

45. Takami, S.; Sato, T.; Mousavand, T.; Ohara, S.; Umetsu, M.; Adschiri, T. Hydrothermal synthesis of surface-modified iron oxide nanoparticles. Mater. Lett. 2007, 61, 4769-4772. [CrossRef]

46. Wan, L.; Yan, S.; Wang, X.; Li, Z.; Zou, Z. Solvothermal synthesis of monodisperse iron oxides with various morphologies and their applications in removal of Cr(VI). Cryst. Eng. Comm. 2011, 13, 2727-2733. [CrossRef]

47. Maity, D.; Ding, J.; Xue, J.M. Synthesis of magnetite nanoparticles by thermal decomposition: Time, temperature, surfactant and solvent effects. Funct. Mater. Lett. 2008, 1, 189-193. [CrossRef]

48. Maity, D.; Choo, S.G.; Yi, J.; Ding, J.; Xue, J.M. Synthesis of magnetite nanoparticles via a solvent-free thermal decomposition route. J. Magn. Magn. Mater. 2009, 321, 1256-1259. [CrossRef]

49. Sun, S.; Zeng, H. Size-controlled synthesis of magnetite nanoparticles. J. Am. Chem. Soc. 2002, 124, 8204-8205. [CrossRef] [PubMed]

50. Yu, W.W.; Falkner, J.C.; Yavuz, C.T.; Colvin, V.L. Synthesis of monodisperse iron oxide nanocrystals by thermal decomposition of iron carboxylate salts. Chem. Commun. 2004, 10, 2306-2307. [CrossRef] [PubMed]

51. Hatakeyama, M.; Kishi, H.; Kita, Y.; Imai, K.; Nishio, K.; Karasawa, S.; Masaike, Y.; Sakamoto, S.; Sandhu, A.; Tanimoto, A.; et al. A two-step ligand exchange reaction generates highly water-dispersed magnetic nanoparticles for biomedical applications. J. Mater. Chem. 2011, 21, 5959-5966. [CrossRef]

52. Belaid, S.; Stanici, D.; Vander Elst, L.; Muller, R.N.; Laurent, S. Influence of experimental parameters on iron oxide nanoparticles properties synthesized by thermal decomposition: Size and nuclear magnetic resonance studies. Nanotechnology 2018. [CrossRef] [PubMed]

53. Pandey, S.; Mishra, S.B. Sol-gel derived organic-inorganic hybrid materials: Synthesis, characterizations and applications. J. Sol-Gel Sci. Technol. 2011, 59, 73-94. [CrossRef] 
54. Xu, J.K.; Zhang, F.F.; Sun, J.J.; Sheng, J.; Wang, F.; Sun, M. Bio and nanomaterials based on $\mathrm{Fe}_{3} \mathrm{O}_{4}$. Molecules 2014, 19, 21506-21528. [CrossRef] [PubMed]

55. Reddy, L.H.; Arias, J.L.; Nicolas, J.; Couvreur, P. Magnetic nanoparticles: Design and characterization, toxicity and biocompatibility, pharmaceutical and biomedical applications. Chem. Rev. 2012, 112, 5818-5878. [CrossRef] [PubMed]

56. Cai, W.; Wan, J. Facile synthesis of superparamagnetic magnetite nanoparticles in liquid polyols. J. Colloid Interface Sci. 2007, 305, 366-370. [CrossRef] [PubMed]

57. Hachani, R.; Lowdell, M.; Birchall, M.; Hervault, A.; Mertz, D.; Begin-Colin, S.; Thanh, N.T. Polyol synthesis, functionalisation, and biocompatibility studies of superparamagnetic iron oxide nanoparticles as potential MRI contrast agents. Nanoscale 2016, 8, 3278-3287. [CrossRef] [PubMed]

58. Sodipo, B.K.; Aziz, A.A. One minute synthesis of amino-silane functionalized superparamagnetic iron oxide nanoparticles by sonochemical method. Ultrason. Sonochem. 2018, 40, 837-840. [CrossRef] [PubMed]

59. Dolores, R.; Raquel, S.; Adianez, G.L. Sonochemical synthesis of iron oxide nanoparticles loaded with folate and cisplatin: Effect of ultrasonic frequency. Ultrason. Sonochem. 2015, 23, 391-398. [CrossRef] [PubMed]

60. Osborne, E.A.; Atkins, T.M.; Gilbert, D.A.; Kauzlarich, S.M.; Liu, K.; Louie, A.Y. Rapid microwave-assisted synthesis of dextran-coated iron oxide nanoparticles for magnetic resonance imaging. Nanotechnology 2012, 23, 215602. [CrossRef] [PubMed]

61. Bomatí-Miguel, O.; Zhao, X.Q.; Martelli, S.; Di Nunzio, P.E.; Veintemillas-Verdaguer, S. Modeling of the laser pyrolysis process by means of the aerosol theory: Case of iron nanoparticles. J. Appl. Phys. 2010, 107, 014906. [CrossRef]

62. Thongsuwan, W.; Suparerk, A.; Singjai, P. Preparation of Iron Oxide nanoparticles by a pyrosol technique. Key Eng. Mater. 2007, 353-358, 2175-2178. [CrossRef]

63. Malumbres, A.; Martínez, G.; Mallada, R.; Hueso, J.L.; Bomatí-Miguel, O.; Santamaría, J. Continuous production of iron-based nanocrystals by laser pyrolysis. Effect of operating variables on size, composition and magnetic response. Nanotechnology 2013, 24, 325603. [CrossRef] [PubMed]

64. Amendola, V.; Meneghetti, M. What controls the composition and the structure of nanomaterials generated by laser ablation in liquid solution? Phys. Chem. Chem. Phys. 2013, 15, 3027-3046. [CrossRef] [PubMed]

65. Fracasso, G.; Ghigna, P.; Nodari, L.; Agnoli, S.; Badocco, D.; Pastore, P.; Nicolato, E.; Marzola, P.; Mihajlović, D.; Markovic, M.; et al. Nanoaggregates of iron poly-oxo-clusters obtained by laser ablation in aqueous solution of phosphonates. J. Colloid Interface Sci. 2018, 522, 208-216. [CrossRef] [PubMed]

66. Fatemi, M.; Mollania, N.; Momeni-Moghaddam, M.; Sadeghifar, F. Extracellular biosynthesis of magnetic iron oxide nanoparticles by Bacillus cereus strain $\mathrm{HMH1}$ : Characterization and in vitro cytotoxicity analysis on MCF-7 and 3T3 cell lines. J. Biotechnol. 2018, 270, 1-11. [CrossRef] [PubMed]

67. Smith, J.A.; Lovley, D.R.; Tremblay, P.L. Outer cell surface components essential for Fe(III) oxide reduction by Geobacter metallireducens. Appl. Environ. Microbiol. 2013, 79, 901-907. [CrossRef] [PubMed]

68. Shenton, W.; Mann, S.; Cölfen, H.; Bacher, A.; Fischer, M. Synthesis of nanophase iron oxide in lumazine synthase capsids. Angew. Chem. Int. Ed. Engl. 2001, 40, 442-445. [CrossRef]

69. Wu, W.; Chen, B.; Cheng, J.; Wang, J.; Xu, W.; Liu, L.; Xia, G.; Wei, H.; Wang, X.; Yang, M.; et al. Biocompatibility of $\mathrm{Fe}_{3} \mathrm{O}_{4} / \mathrm{DNR}$ magnetic nanoparticles in the treatment of hematologic malignancies. Int. J. Nanomed. 2010, 5, 1079-1084. [CrossRef]

70. Couto, D.; Freitas, M.; Carvalho, F.; Fernandes, E. Iron oxide nanoparticles: An insight into their biomedical applications. Curr. Med. Chem. 2015, 22, 1808-1828. [CrossRef] [PubMed]

71. Prabhu, S.; Mutalik, S.; Rai, S.; Udupa, N.; Rao, B.S.S. PEGylation of superparamagnetic iron oxide nanoparticle for drug delivery applications with decreased toxicity: An in vivo study. J. Nanopart. Res. 2015, 17, 412. [CrossRef]

72. Ramírez-Cando, L.J.; De Simone, U.; Coccini, T. Toxicity evaluation of iron oxide $\left(\mathrm{Fe}_{3} \mathrm{O}_{4}\right)$ nanoparticles on human neuroblastoma-derived SH-SY5Y cell line. J. Nanosci. Nanotechnol. 2017, 17, 203-211. [CrossRef] [PubMed]

73. Chomoucka, J.; Drbohlavova, J.; Huska, D.; Adam, V.; Kizek, R.; Hubalek, J. Magnetic nanoparticles and targeted drug delivering. Pharm. Res. 2010, 62, 144-149. [CrossRef] [PubMed]

74. Makadia, H.K.; Siegel, S.J. Poly lactic-co-glycolic acid (PLGA) as biodegradable controlled drug delivery carrier. Polymers 2011, 3, 1377-1397. [CrossRef] [PubMed] 
75. Houchin, M.L.; Topp, E.M. Physical properties of PLGA films during polymer degradation. J. Appl. Polym. Sci. 2009, 114, 2848-2854. [CrossRef]

76. Abdalla, M.O.; Aneja, R.; Dean, D.; Rangari, V.; Russell, A.; Jaynes, J.; Yates, C.; Turner, T. Synthesis and characterization of noscapine loaded magnetic polymeric nanoparticles. J. Magn. Magn. Mater. 2010, 322, 190-196. [CrossRef] [PubMed]

77. Agnihotri, S.A.; Mallikarjuna, N.N.; Aminabhavi, T.M. Recent advances on chitosan-based micro- and nanoparticles in drug delivery. J. Control. Release 2004, 100, 5-28. [CrossRef] [PubMed]

78. Berscht, P.C.; Nies, B.; Liebendörfer, A.; Kreuter, J. Incorporation of basic fibroblast growth factor into methylpyrrolidinone chitosan fleeces and determination of the in vitro release characteristics. Biomaterials 1994, 15, 593-600. [CrossRef]

79. Arai, K.; Kinumaki, T.; Fujita, T. Toxicity of chitosan. Bull. Tokai Reg. Fish. Lab. 1968, 43, 89-94.

80. Nicol, S. Life after death for empty shells: Crustacean fisheries create a mountain of waste shells, made of a strong natural polymer, chitin. Now chemists are helping to put this waste to some surprising uses. New Sci. 1991, 129, 46-48.

81. Qi, L.; Xu, Z.; Jiang, X.; Hu, C.; Zou, X. Preparation and antibacterial activity of chitosan nanoparticles. Carbohydr. Res. 2004, 339, 2693-2700. [CrossRef] [PubMed]

82. Yang, S.J.; Shieh, M.J.; Lin, F.H.; Lou, P.J.; Peng, C.L.; Wei, M.F.; Yao, C.J.; Lai, P.S.; Young, T.H. Colorectal cancer cell detection by 5-aminolaevulinic acid-loaded chitosan nano-particles. Cancer Lett. 2009, 273, 210-220. [CrossRef] [PubMed]

83. Sun, Y.; Chen, Z.L.; Yang, X.X.; Huang, P.; Zhou, X.P.; Du, X.X. Magnetic chitosan nanoparticles as a drug delivery system for targeting photodynamic therapy. Nanotechnology 2009, 20, 135102. [CrossRef] [PubMed]

84. Mathew, T.V.; Kuriakose, S. Photochemical and antimicrobial properties of silver nanoparticle-encapsulated chitosan functionalized with photoactive groups. Mater. Sci. Eng. C Mater. Biol. Appl. 2013, 33, 4409-4415. [CrossRef] [PubMed]

85. Zhou, W.; Wang, Y.; Jian, J.; Song, S. Self-aggregated nanoparticles based on amphiphilic poly(lactic acid)-grafted-chitosan copolymer for ocular delivery of amphotericin B. Int. J. Nanomed. 2013, 8, 3715-3728. [CrossRef]

86. Radulescu, M.; Ficai, D.; Oprea, O.; Ficai, A.; Andronescu, E.; Holban, A.M. Antimicrobial chitosan based formulations with impact on different biomedical applications. Curr. Pharm. Biotechnol. 2015, 16, 128-136. [CrossRef] [PubMed]

87. Onnainty, R.; Onida, B.; Páez, P.; Longhi, M.; Barresi, A.; Granero, G. Targeted chitosan-based bionanocomposites for controlled oral mucosal delivery of chlorhexidine. Int. J. Pharm. 2016, 509, 408-418. [CrossRef] [PubMed]

88. Li, L.; Chen, D.; Zhang, Y.; Deng, Z.; Ren, X.; Meng, X.; Tang, F.; Ren, J.; Zhang, L. Magnetic and fluorescent multifunctional chitosan nanoparticles as a smart drug delivery system. Nanotechnology 2007, 18, 405102. [CrossRef]

89. Soares, P.I.; Machado, D.; Laia, C.; Pereira, L.C.; Coutinho, J.T.; Ferreira, I.M.; Novo, C.M.; Borges, J.P. Thermal and magnetic properties of chitosan-iron oxide nanoparticles. Carbohydr. Polym. 2016, 149, 382-390. [CrossRef] [PubMed]

90. Gupta, A.K.; Gupta, M. Synthesis and surface engineering of iron oxide nanoparticles for biomedical applications. Biomaterials 2005, 26, 3995-4021. [CrossRef] [PubMed]

91. Prabaharan, M. Review paper: Chitosan derivatives as promising materials for controlled drug delivery. J. Biomater. Appl. 2008, 23, 5-36. [CrossRef] [PubMed]

92. Zhu, A.; Chan-Park, M.B.; Dai, S.; Li, L. The aggregation behavior of O-carboxymethylchitosan in dilute aqueous solution. Colloids Surf. B Biointerfaces 2005, 43, 143-149. [CrossRef] [PubMed]

93. Saikia, C.; Hussain, A.; Ramteke, A.; Sharma, H.K.; Maji, T.K. Carboxymethyl starch-chitosan-coated iron oxide magnetic nanoparticles for controlled delivery of isoniazid. J. Microencapsul. 2015, 32, 29-39. [CrossRef] [PubMed]

94. Soares, P.I.; Lochte, F.; Echeverria, C.; Pereira, L.C.; Coutinho, J.T.; Ferreira, I.M.; Novo, C.M.; Borges, J.P. Thermal and magnetic properties of iron oxide colloids: Influence of surfactants. Nanotechnology 2015, 26, 425704. [CrossRef] [PubMed] 
95. Wang, Y.; Wong, J.F.; Teng, X.; Lin, X.Z.; Yang, H. “Pulling” nanoparticles into water: Phase transfer of oleic acid stabilized monodisperse nanoparticles into aqueous solutions of alpha-cyclodextrin. Nano Lett. 2003, 3, 7907-7911. [CrossRef]

96. Costa, C.; Brandão, F.; Bessa, M.J.; Costa, S.; Valdiglesias, V.; Kiliç, G.; Fernández-Bertólez, N.; Quaresma, P.; Pereira, E.; Pásaro, E.; et al. In vitro cytotoxicity of superparamagnetic iron oxide nanoparticles on neuronal and glial cells. Evaluation of nanoparticle interference with viability tests. J. Appl. Toxicol. 2016, 36, 361-372. [CrossRef] [PubMed]

97. Toropova, Y.G.; Golovkin, A.S.; Malashicheva, A.B.; Korolev, D.V.; Gorshkov, A.N.; Gareev, K.G.; Afonin, M.V.; Galagudza, M.M. In vitro toxicity of FemOn, FemOn-SiO ${ }_{2}$ composite, and $\mathrm{SiO}_{2}-\mathrm{FemOn}$ core-shell magnetic nanoparticles. Int. J. Nanomed. 2017, 12, 593-603. [CrossRef] [PubMed]

98. Kandibanda, S.R.; Gundeboina, N.; Das, S.; Sunkara, V.M. Synthesis, characterisation, cellular uptake and cytotoxicity of functionalised magnetic ruthenium (II) polypyridine complex core-shell nanocomposite. J. Photochem. Photobiol. B 2018, 178, 270-276. [CrossRef] [PubMed]

99. Ma, K.; Wang, Q.; Rong, Q.; Zhang, D.; Cui, S.; Yang, J. Preparation of magnetic carbon $/ \mathrm{Fe}_{3} \mathrm{O}_{4}$ supported zero-valent iron composites and their application in $\mathrm{Pb}$ (II) removal from aqueous solutions. Water Sci. Technol. 2017, 76, 2680-2689. [CrossRef] [PubMed]

100. Ivashchenko, O.; Lewandowski, M.; Peplińska, B.; Jarek, M.; Nowaczyk, G.; Wiesner, M.; Załęski, K.; Babutina, T.; Warowicka, A.; Jurga, S. Synthesis and characterization of magnetite/silver/antibiotic nanocomposites for targeted antimicrobial therapy. Mater. Sci. Eng. C Mater. Biol. Appl. 2015, 55, 343-359. [CrossRef] [PubMed]

101. Tamer, U.; Gündoğdu, Y.; Boyaci, I.H.; Pekmez, K. Synthesis of magnetic core-shell $\mathrm{Fe}_{3} \mathrm{O}_{4}$-Au, nanoparticles for biomolecule immobilization and detection. J. Nanopart. Res. 2010, 12, 1187-1196. [CrossRef]

102. Bisht, G.; Rayamajhi, S.; Kc, B.; Paudel, S.N.; Karna, D.; Shrestha, B.G. Synthesis, characterization, and study of in vitro cytotoxicity of $\mathrm{ZnO}-\mathrm{Fe}_{3} \mathrm{O}_{4}$ magnetic composite nanoparticles in human breast cancer cell line (MDA-MB-231) and mouse fibroblast (NIH 3T3). Nanoscale Res. Lett. 2016, 11, 537. [CrossRef] [PubMed]

103. Rădulescu, M.; Andronescu, E.; Holban, A.M.; Vasile, B.S.; Iordache, F.; Mogoantă, L.; Mogoșanu, G.D.; Grumezescu, A.M.; Georgescu, M.; Chifiriuc, M.C. Antimicrobial nanostructured bioactive coating based on $\mathrm{Fe}_{3} \mathrm{O}_{4}$ and patchouli oil for wound dressing. Metals 2016, 6, 103. [CrossRef]

104. Mu, Q.; Kievit, F.M.; Kant, R.J.; Lin, G.; Jeon, M.; Zhang, M. Anti-HER2/neu peptide-conjugated iron oxide nanoparticles for targeted delivery of paclitaxel to breast cancer cells. Nanoscale 2015, 7, 18010-18014. [CrossRef] [PubMed]

105. Jahanban-Esfahlan, A.; Dastmalchi, S.; Davaran, S. A simple improved desolvation method for the rapid preparation of albumin nanoparticles. Int. J. Biol. Macromol. 2016, 91, 703-709. [CrossRef] [PubMed]

106. Nosrati, H.; Sefidi, N.; Sharafi, A.; Danafar, H.; Kheiri Manjili, H. Bovine Serum Albumin (BSA) coated iron oxide magnetic nanoparticles as biocompatible carriers for curcumin-anticancer drug. Bioorg. Chem. 2018, 76, 501-509. [CrossRef] [PubMed]

107. Thomas, R.G.; Unnithan, A.R.; Moon, M.J.; Surendran, S.P.; Batgerel, T.; Park, C.H.; Kim, C.S.; Jeong, Y.Y. Electromagnetic manipulation enabled calcium alginate Janus microsphere for targeted delivery of mesenchymal stem cells. Int. J. Biol. Macromol. 2018, 110, 465-471. [CrossRef] [PubMed]

108. Hans, M.L.; Lowman, A.M. Nanoparticles for Drug Delivery. In Nanomaterials Handbook, 1st ed.; Gogotsi, Y., Ed.; Taylor \& Francis: Boca Raton, FL, USA, 2006; pp. 637-664. ISBN 0-8493-2308-8.

109. Pillai, G. Nanomedicines for cancer therapy: An update of FDA approved and those under various stages of development. SOJ Pharm. Pharm. Sci. 2014, 2, 1-13. [CrossRef]

110. Ebrahimi, E.; Akbarzadeh, A.; Abbasi, E.; Khandaghi, A.A.; Abasalizadeh, F.; Davaran, S. Novel drug delivery system based on doxorubicin-encapsulated magnetic nanoparticles modified with PLGA-PEG 1000 copolymer. Artif. Cells Nanomed. Biotechnol. 2016, 44, 290-297. [CrossRef] [PubMed]

111. Nigam, S.; Bahadur, D. Doxorubicin-loaded dendritic-Fe $\mathrm{O}_{4}$ supramolecular nanoparticles for magnetic drug targeting and tumor regression in spheroid murine melanoma model. Nanomedicine 2018, 14, 759-768. [CrossRef] [PubMed]

112. Abbasi Aval, N.; Pirayesh Islamian, J.; Hatamian, M.; Arabfirouzjaei, M.; Javadpour, J.; Rashidi, M.R. Doxorubicin loaded large-pore mesoporous hydroxyapatite coated superparamagnetic $\mathrm{Fe}_{3} \mathrm{O}_{4}$ nanoparticles for cancer treatment. Int. J. Pharm. 2016, 509, 159-167. [CrossRef] [PubMed] 
113. Liang, P.C.; Chen, Y.C.; Chiang, C.F.; Mo, L.R.; Wei, S.Y.; Hsieh, W.Y.; Lin, W.L. Doxorubicin-modified magnetic nanoparticles as a drug delivery system for magnetic resonance imaging-monitoring magnet-enhancing tumor chemotherapy. Int. J. Nanomed. 2016, 11, 2021-2037. [CrossRef]

114. Augustin, E.; Czubek, B.; Nowicka, A.M.; Kowalczyk, A.; Stojek, Z.; Mazerska, Z. Improved cytotoxicity and preserved level of cell death induced in colon cancer cells by doxorubicin after its conjugation with iron-oxide magnetic nanoparticles. Toxicol. In Vitro 2016, 33, 45-53. [CrossRef] [PubMed]

115. Jurado, R.; Frączek, P.; Droetto, M.; Sánchez, P.; Valero, E.; Domínguez-Vera, J.M.; Gálvez, N. Apomaghemite as a doxorubicin carrier for anticancer drug delivery. J. Inorg. Biochem. 2016, 157, 46-51. [CrossRef] [PubMed]

116. Montha, W.; Maneeprakorn, W.; Buatong, N.; Tang, I.M.; Pon-On, W. Synthesis of doxorubicin-PLGA loaded chitosan stabilized (Mn, $\mathrm{Zn}) \mathrm{Fe}_{2} \mathrm{O}_{4}$ nanoparticles: Biological activity and $\mathrm{pH}$-responsive drug release. Mater. Sci. Eng. C Mater. Biol. Appl. 2016, 59, 235-240. [CrossRef] [PubMed]

117. Mallick, N.; Anwar, M.; Asfer, M.; Mehdi, S.H.; Rizvi, M.M.; Panda, A.K.; Talegaonkar, S.; Ahmad, F.J. Chondroitin sulfate-capped super-paramagnetic iron oxide nanoparticles as potential carriers of doxorubicin hydrochloride. Carbohydr. Polym. 2016, 151, 546-556. [CrossRef] [PubMed]

118. Nadeem, M.; Ahmad, M.; Akhtar, M.S.; Shaari, A.; Riaz, S.; Naseem, S.; Masood, M.; Saeed, M.A. Magnetic properties of polyvinyl alcohol and doxorubicine loaded iron oxide nanoparticles for anticancer drug delivery applications. PLoS ONE 2016, 11, e0158084. [CrossRef] [PubMed]

119. Tarvirdipour, S.; Vasheghani-Farahani, E.; Soleimani, M.; Bardania, H. Functionalized magnetic dextran-spermine nanocarriers for targeted delivery of doxorubicin to breast cancer cells. Int. J. Pharm. 2016, 501, 331-341. [CrossRef] [PubMed]

120. Thorat, N.D.; Lemine, O.M.; Bohara, R.A.; Omri, K.; El Mir, L.; Tofail, S.A. Superparamagnetic iron oxide nanocargoes for combined cancer thermotherapy and MRI applications. Phys. Chem. Chem. Phys. 2016, 18, 21331-21339. [CrossRef] [PubMed]

121. Wang, Y.; Zhao, R.; Wang, S.; Liu, Z.; Tang, R. In vivo dual-targeted chemotherapy of drug resistant cancer by rationally designed nanocarrier. Biomaterials 2016, 75, 71-81. [CrossRef] [PubMed]

122. Nehate, C.; Aji Alex, M.R.; Kumar, A.; Koul, V. Combinatorial delivery of superparamagnetic iron oxide nanoparticles $\left(\gamma \mathrm{Fe}_{2} \mathrm{O}_{3}\right)$ and doxorubicin using folate conjugated redox sensitive multiblock polymeric nanocarriers for enhancing the chemotherapeutic efficacy in cancer cells. Mater. Sci. Eng. C Mater. Biol. Appl. 2017, 75, 1128-1143. [CrossRef] [PubMed]

123. Wu, L.; Chen, L.; Liu, F.; Qi, X.; Ge, Y.; Shen, S. Remotely controlled drug release based on iron oxide nanoparticles for specific therapy of cancer. Colloids Surf. B Biointerfaces 2017, 152, 440-448. [CrossRef] [PubMed]

124. Bekaroglu, M.G.; Isci, Y.; Isci, S. Colloidal properties and in vitro evaluation of Hydroxy ethyl cellulose coated iron oxide particles for targeted drug delivery. Mater. Sci. Eng. C Mater. Biol. Appl. 2017, 78, 847-853. [CrossRef] [PubMed]

125. Benyettou, F.; Alhashimi, M.; O’Connor, M.; Pasricha, R.; Brandel, J.; Traboulsi, H.; Mazher, J.; Olsen, J.C.; Trabolsi, A. Sequential delivery of doxorubicin and zoledronic acid to breast cancer cells by CB[7]-modified iron oxide nanoparticles. ACS Appl. Mater. Interfaces 2017, 9, 40006-40016. [CrossRef] [PubMed]

126. Mosafer, J.; Teymouri, M. Comparative study of superparamagnetic iron oxide/doxorubicin co-loaded poly (lactic-co-glycolic acid) nanospheres prepared by different emulsion solvent evaporation methods. Artif. Cells Nanomed. Biotechnol. 2017, 46,1-10. [CrossRef] [PubMed]

127. Mosafer, J.; Teymouri, M.; Abnous, K.; Tafaghodi, M.; Ramezani, M. Study and evaluation of nucleolin-targeted delivery of magnetic PLGA-PEG nanospheres loaded with doxorubicin to C6 glioma cells compared with low nucleolin-expressing L929 cells. Mater. Sci. Eng. C Mater. Biol. Appl. 2017, 72, 123-133. [CrossRef] [PubMed]

128. Prabha, G.; Raj, V. Sodium alginate-polyvinyl alcohol-bovin serum albumin coated $\mathrm{Fe}_{3} \mathrm{O}_{4}$ nanoparticles as anticancer drug delivery vehicle: Doxorubicin loading and in vitro release study and cytotoxicity to HepG2 and L02 cells. Mater. Sci. Eng. C Mater. Biol. Appl. 2017, 79, 410-422. [CrossRef] [PubMed]

129. Islam, M.S.; Haque, P.; Rashid, T.U.; Khan, M.N.; Mallik, A.K.; Khan, M.N.; Khan, M.; Rahman, M.M. Core-shell drug carrier from folate conjugated chitosan obtained from prawn shell for targeted doxorubicin delivery. J. Mater. Sci. Mater. Med. 2017, 28, 55. [CrossRef] [PubMed] 
130. Mu, X.; Zhang, F.; Kong, C.; Zhang, H.; Zhang, W.; Ge, R.; Liu, Y.; Jiang, J. EGFR-targeted delivery of DOX-loaded $\mathrm{Fe}_{3} \mathrm{O}_{4} @$ polydopamine multifunctional nanocomposites for MRI and antitumor chemo-photothermal therapy. Int. J. Nanomed. 2017, 12, 2899-2911. [CrossRef] [PubMed]

131. Arachchige, M.P.; Laha, S.S.; Naik, A.R.; Lewis, K.T.; Naik, R.; Jena, B.P. Functionalized nanoparticles enable tracking the rapid entry and release of doxorubicin in human pancreatic cancer cells. Micron 2017, 92, $25-31$. [CrossRef] [PubMed]

132. Pan, C.; Liu, Y.; Zhou, M.; Wang, W.; Shi, M.; Xing, M.; Liao, W. Theranostic pH-sensitive nanoparticles for highly efficient targeted delivery of doxorubicin for breast tumor treatment. Int. J. Nanomed. 2018, 13, 1119-1137. [CrossRef] [PubMed]

133. Dutta, B.; Shetake, N.G.; Barick, B.K.; Barick, K.C.; Pandey, B.N.; Priyadarsini, K.I.; Hassan, P.A. pH sensitive surfactant-stabilized $\mathrm{Fe}_{3} \mathrm{O}_{4}$ magnetic nanocarriers for dual drug delivery. Colloids Surf. B Biointerfaces 2018, 162, 163-171. [CrossRef] [PubMed]

134. Ji, F.; Zhang, K.; Li, J.; Gu, Y.; Zhao, J.; Zhang, J. A Dual pH/magnetic responsive nanocarrier based on PEGylated $\mathrm{Fe}_{3} \mathrm{O}_{4}$ nanoparticles for doxorubicin delivery. J. Nanosci. Nanotechnol. 2018, 18, 4464-4470. [CrossRef] [PubMed]

135. Shelat, R.; Chandra, S.; Khanna, A. Detailed toxicity evaluation of beta-cyclodextrin coated iron oxide nanoparticles for biomedical applications. Int. J. Biol. Macromol. 2018, 110, 357-365. [CrossRef] [PubMed]

136. Akilo, O.D.; Choonara, Y.E.; Strydom, A.M.; du Toit, L.C.; Kumar, P.; Modi, G.; Pillay, V. An in vitro evaluation of a carmustine-loaded Nano-co-Plex for potential magnetic-targeted intranasal delivery to the brain. Int. J. Pharm. 2016, 500, 196-209. [CrossRef] [PubMed]

137. Freeman, A.C.; Platt, S.R.; Holmes, S.; Kent, M.; Robinson, K.; Howerth, E.; Eagleson, J.; Bouras, A.; Kaluzova, M.; Hadjipanayis, C.G. Convection-enhanced delivery of cetuximab conjugated iron-oxide nanoparticles for treatment of spontaneous canine intracranial gliomas. J. Neurooncol. 2018. [CrossRef] [PubMed]

138. Tseng, S.H.; Chou, M.Y.; Chu, I.M. Cetuximab-conjugated iron oxide nanoparticles for cancer imaging and therapy. Int. J. Nanomed. 2015, 10, 3663-3685. [CrossRef]

139. Kaluzova, M.; Bouras, A.; Machaidze, R.; Hadjipanayis, C.G. Targeted therapy of glioblastoma stem-like cells and tumor non-stem cells using cetuximab-conjugated iron-oxide nanoparticles. Oncotarget 2015, 6, 8788-8806. [CrossRef] [PubMed]

140. Shahabadi, N.; Falsafi, H.; Mansouri, K. Improving antiproliferative effect of the anticancer drug cytarabine on human promyelocytic leukemia cells by coating on $\mathrm{Fe}_{3} \mathrm{O}_{4} @ \mathrm{SiO}_{2}$ nanoparticles. Colloids Surf. B Biointerfaces 2016, 141, 213-222. [CrossRef] [PubMed]

141. Liu, M.C.; Jin, S.F.; Zheng, M.; Wang, Y.; Zhao, P.L.; Tang, D.T.; Chen, J.; Lin, J.Q.; Wang, X.H.; Zhao, P. Daunomycin-loaded superparamagnetic iron oxide nanoparticles: Preparation, magnetic targeting, cell cytotoxicity, and protein delivery research. J. Biomater. Appl. 2016, 31, 261-272. [CrossRef] [PubMed]

142. Al-Jamal, K.T.; Bai, J.; Wang, J.T.; Protti, A.; Southern, P.; Bogart, L.; Heidari, H.; Li, X.; Cakebread, A.; Asker, D.; et al. Magnetic drug targeting: Preclinical in vivo studies, mathematical modeling, and extrapolation to humans. Nano Lett. 2016, 16, 5652-5660. [CrossRef] [PubMed]

143. Nagesh, P.K.; Johnson, N.R.; Boya, V.K.; Chowdhury, P.; Othman, S.F.; Khalilzad-Sharghi, V.; Hafeez, B.B.; Ganju, A.; Khan, S.; Behrman, S.W.; et al. PSMA targeted docetaxel-loaded superparamagnetic iron oxide nanoparticles for prostate cancer. Colloids Surf. B Biointerfaces 2016, 144, 8-20. [CrossRef] [PubMed]

144. Rao, Y.F.; Chen, W.; Liang, X.G.; Huang, Y.Z.; Miao, J.; Liu, L.; Lou, Y.; Zhang, X.G.; Wang, B.; Tang, R.K.; et al. Epirubicin-loaded superparamagnetic iron-oxide nanoparticles for transdermal delivery: Cancer therapy by circumventing the skin barrier. Small 2015, 11, 239-247. [CrossRef] [PubMed]

145. Alupei, L.; Peptu, C.A.; Lungan, A.M.; Desbrieres, J.; Chiscan, O.; Radji, S.; Popa, M. New hybrid magnetic nanoparticles based on chitosan-maltose derivative for antitumor drug delivery. Int. J. Biol. Macromol. 2016, 92, 561-572. [CrossRef] [PubMed]

146. Prabha, G.; Raj, V. Formation and characterization of b-cyclodextrin (b-CD)-polyethyleneglycol (PEG)-polyethyleneimine (PEI) coated $\mathrm{Fe}_{3} \mathrm{O}_{4}$ nanoparticles for loading and releasing 5-Fluorouracil drug. Biomed. Pharmacother. 2016, 80, 173-182. [CrossRef] [PubMed]

147. Esmaelbeygi, E.; Khoei, S.; Khoee, S.; Eynali, S. Role of iron oxide core of polymeric nanoparticles in the thermosensitivity of colon cancer cell line HT-29. Int. J. Hyperth. 2015, 31, 489-497. [CrossRef] [PubMed] 
148. Eynali, S.; Khoei, S.; Khoei, S.; Esmaelbeygi, E. Evaluation of the cytotoxic effects of hyperthermia and 5-fluorouracil loaded magnetic nanoparticles on human colon cancer cell line HT-29. Int. J. Hyperth. 2016, 1-33. [CrossRef] [PubMed]

149. Hashemi-Moghaddam, H.; Kazemi-Bagsangani, S.; Jamili, M.; Zavareh, S. Evaluation of magnetic nanoparticles coated by 5-fluorouracil imprinted polymer for controlled drug delivery in mouse breast cancer model. Int. J. Pharm. 2016, 497, 228-238. [CrossRef] [PubMed]

150. Sağir, T.; Huysal, M.; Durmus, Z.; Kurt, B.Z.; Senel, M.; Isık, S. Preparation and in vitro evaluation of 5-flourouracil loaded magnetite-zeolite nanocomposite (5-FU-MZNC) for cancer drug delivery applications. Biomed. Pharmacother. 2016, 77, 182-189. [CrossRef] [PubMed]

151. Şanlı, O.; Kahraman, A.; Kondolot Solak, E.; Olukman, M. Preparation of magnetite-chitosan/methylcellulose nanospheres by entrapment and adsorption techniques for targeting the anti-cancer drug 5-fluorouracil. Artif. Cells Nanomed. Biotechnol. 2016, 44, 950-959. [CrossRef] [PubMed]

152. Tuncelli, G.; Ay, A.N.; Zümreoglu-Karan, B. 5-Fluorouracil intercalated iron oxide@layered double hydroxide core-shell nano-composites with isotropic and anisotropic architectures for shape-selective drug delivery applications. Mater. Sci. Eng. C Mater. Biol. Appl. 2015, 55, 562-568. [CrossRef] [PubMed]

153. Asadi, N.; Annabi, N.; Mostafavi, E.; Anzabi, M.; Khalilov, R.; Saghfi, S.; Mehrizadeh, M.; Akbarzadeh, A. Synthesis, characterization and in vitro evaluation of magnetic nanoparticles modified with PCL-PEG-PCL for controlled delivery of 5FU. Artif. Cells Nanomed. Biotechnol. 2018. [CrossRef] [PubMed]

154. Mu, Q.; Lin, G.; Patton, V.K.; Wang, K.; Press, O.W.; Zhang, M. Gemcitabine and chlorotoxin conjugated iron oxide nanoparticles for glioblastoma therapy. J. Mater. Chem. B Mater. Biol. Med. 2016, 4, 32-36. [CrossRef] [PubMed]

155. Aires, A.; Ocampo, S.M.; Simões, B.M.; Josefa Rodríguez, M.; Cadenas, J.F.; Couleaud, P.; Spence, K.; Latorre, A.; Miranda, R.; Somoza, Á.; et al. Multifunctionalized iron oxide nanoparticles for selective drug delivery to CD44-positive cancer cells. Nanotechnology 2016, 27, 065103. [CrossRef] [PubMed]

156. Ferreira, R.V.; Martins, T.M.; Goes, A.M.; Fabris, J.D.; Cavalcante, L.C.; Outon, L.E.; Domingues, R.Z. Termosensitive gemcitabine-magnetoliposomes for combined hyperthermia and chemotherapy. Nanotechnology 2016, 27, 085105. [CrossRef] [PubMed]

157. Hamarat Sanlıer, S.; Yasa, M.; Cihnioglu, A.O.; Abdulhayoglu, M.; Yılmaz, H.; Ak, G. Development of gemcitabine-adsorbed magnetic gelatin nanoparticles for targeted drug delivery in lung cancer. Artif. Cells Nanomed. Biotechnol. 2016, 44, 943-949. [CrossRef] [PubMed]

158. Jaidev, L.R.; Chellappan, D.R.; Bhavsar, D.V.; Ranganathan, R.; Sivanantham, B.; Subramanian, A.; Sharma, U.; Jagannathan, N.R.; Krishnan, U.M.; Sethuraman, S. Multi-functional nanoparticles as theranostic agents for the treatment \& imaging of pancreatic cancer. Acta Biomater. 2017, 49, 422-433. [CrossRef] [PubMed]

159. Lin, J.; Li, Y.; Li, Y.; Wu, H.; Yu, F.; Zhou, S.; Xie, L.; Luo, F.; Lin, C.; Hou, Z. Drug/dye-loaded, multifunctional PEG-chitosan-iron oxide nanocomposites for methotraxate synergistically self-targeted cancer therapy and dual model imaging. ACS Appl. Mater. Interfaces 2015, 7, 11908-11920. [CrossRef] [PubMed]

160. Jahangiri, S.; Akbarzadeh, A. Preparation and in vitro evaluation of Methotrexate-loaded magnetic nanoparticles modified with biocompatible copolymers. Artif. Cells Nanomed. Biotechnol. 2016, 44, 1733-1740. [CrossRef] [PubMed]

161. Nosrati, H.; Salehiabar, M.; Davaran, S.; Danafar, H.; Manjili, H.K. Methotrexate-conjugated L-lysine coated iron oxide magnetic nanoparticles for inhibition of MCF-7 breast cancer cells. Drug Dev. Ind. Pharm. 2017, 1-9. [CrossRef] [PubMed]

162. Barar, J.; Kafil, V.; Majd, M.H.; Barzegari, A.; Khani, S.; Johari-Ahar, M.; Asgari, D.; Coukos, G.; Omidi, Y. Multifunctional mitoxantrone-conjugated magnetic nanosystem for targeted therapy of folate receptor-overexpressing malignant cells. J. Nanobiotechnol. 2015, 13, 26. [CrossRef] [PubMed]

163. Cicha, I.; Scheffler, L.; Ebenau, A.; Lyer, S.; Alexiou, C.; Goppelt-Struebe, M. Mitoxantrone-loaded superparamagnetic iron oxide nanoparticles as drug carriers for cancer therapy: Uptake and toxicity in primary human tubular epithelial cells. Nanotoxicology 2016, 10, 557-566. [CrossRef] [PubMed]

164. Hornung, A.; Poettler, M.; Friedrich, R.P.; Zaloga, J.; Unterweger, H.; Lyer, S.; Nowak, J.; Odenbach, S.; Alexiou, C.; Janko, C. Treatment efficiency of free and nanoparticle-loaded mitoxantrone for magnetic drug targeting in multicellular tumor spheroids. Molecules 2015, 20, 18016-18030. [CrossRef] [PubMed] 
165. Zaloga, J.; Pöttler, M.; Leitinger, G.; Friedrich, R.P.; Almer, G.; Lyer, S.; Baum, E.; Tietze, R.; Heimke-Brinck, R.; Mangge, H.; et al. Pharmaceutical formulation of HSA hybrid coated iron oxide nanoparticles for magnetic drug targeting. Eur. J. Pharm. Biopharm. 2016, 101, 152-162. [CrossRef] [PubMed]

166. Hsiao, M.H.; Mu, Q.; Stephen, Z.R.; Fang, C.; Zhang, M. Hexanoyl-chitosan-PEG copolymer coated iron oxide nanoparticles for hydrophobic drug delivery. ACS Macro Lett. 2015, 4, 403-407. [CrossRef] [PubMed]

167. Jeon, H.; Kim, J.; Lee, Y.M.; Kim, J.; Choi, H.W.; Lee, J.; Park, H.; Kang, Y.; Kim, I.S.; Lee, B.H.; et al. Poly-paclitaxel/cyclodextrin-SPION nano-assembly for magnetically guided drug delivery system. J. Control Release 2016, 231, 68-76. [CrossRef] [PubMed]

168. Lee, J.Y.; Carugo, D.; Crake, C.; Owen, J.; de Saint Victor, M.; Seth, A.; Coussios, C.; Stride, E. Nanoparticle-loaded protein-polymer nanodroplets for improved stability and conversion efficiency in ultrasound imaging and drug delivery. Adv. Mater. 2015, 27, 5484-5492. [CrossRef] [PubMed]

169. Nguyen, D.H.; Lee, J.S.; Choi, J.H.; Park, K.M.; Lee, Y.; Park, K.D. Hierarchical self-assembly of magnetic nanoclusters for theranostics: Tunable size, enhanced magnetic resonance imagability, and controlled and targeted drug delivery. Acta Biomater. 2016, 35, 109-117. [CrossRef] [PubMed]

170. Ruggiero, M.R.; Crich, S.G.; Sieni, E.; Sgarbossa, P.; Forzan, M.; Cavallari, E.; Stefania, R.; Dughiero, F.; Aime, S. Magnetic hyperthermia efficiency and (1)H-NMR relaxation properties of iron oxide/paclitaxel-loaded PLGA nanoparticles. Nanotechnology 2016, 27, 285104. [CrossRef] [PubMed]

171. Swain, A.K.; Pradhan, L.; Bahadur, D. Polymer Stabilized $\mathrm{Fe}_{3} \mathrm{O}_{4}$-graphene as an amphiphilic drug carrier for thermo-chemotherapy of cancer. ACS Appl. Mater. Interfaces 2015, 7, 8013-8022. [CrossRef] [PubMed]

172. Li, X.; Yang, Y.; Jia, Y.; Pu, X.; Yang, T.; Wang, Y.; Ma, X.; Chen, Q.; Sun, M.; Wei, D.; et al. Enhanced tumor targeting effects of a novel paclitaxel-loaded polymer: PEG-PCCL-modified magnetic iron oxide nanoparticles. Drug Deliv. 2017, 24, 1284-1294. [CrossRef] [PubMed]

173. Patra, S.; Roy, E.; Karfa, P.; Kumar, S.; Madhuri, R.; Sharma, P.K. Dual-responsive polymer coated superparamagnetic nanoparticle for targeted drug delivery and hyperthermia treatment. ACS Appl. Mater. Interfaces 2015, 7, 9235-9246. [CrossRef] [PubMed]

174. Prabha, G.; Raj, V. Preparation and characterization of chitosan-Polyethylene glycol-polyvinylpyrrolidone-coated superparamagnetic iron oxide nanoparticles as carrier system: Drug loading and in vitro drug release study. J. Biomed. Mater. Res. B Appl. Biomater. 2016, 104, 808-816. [CrossRef] [PubMed]

175. Mancarella, S.; Greco, V.; Baldassarre, F.; Vergara, D.; Maffia, M.; Leporatti, S. Polymer-coated magnetic nanoparticles for curcumin delivery to cancer cells. Macromol. Biosci. 2015, 15, 1365-1374. [CrossRef] [PubMed]

176. Unterweger, H.; Subatzus, D.; Tietze, R.; Janko, C.; Poettler, M.; Stiegelschmitt, A.; Schuster, M.; Maake, C.; Boccaccini, A.R.; Alexiou, C. Hypericin-bearing magnetic iron oxide nanoparticles for selective drug delivery in photodynamic therapy. Int. J. Nanomed. 2015, 10, 6985-6996. [CrossRef] [PubMed]

177. Sreeja, S.; Krishnan Nair, C.K. Tumor control by hypoxia-specific chemotargeting of iron-oxide nanoparticle-Berberine complexes in a mouse model. Life Sci. 2018, 195, 71-80. [CrossRef] [PubMed]

178. Bilcu, M.; Grumezescu, A.M.; Oprea, A.E.; Popescu, R.C.; Mogoșanu, G.D.; Hristu, R.; Stanciu, G.A.; Mihailescu, D.F.; Lazar, V.; Bezirtzoglou, E.; et al. Efficiency of vanilla, patchouli and ylang ylang essential oils stabilized by iron oxide@C14 nanostructures against bacterial adherence and biofilms formed by Staphylococcus aureus and Klebsiella pneumoniae clinical strains. Molecules 2014, 19, 17943-17956. [CrossRef] [PubMed]

179. Sollinger, H.W. Mycophenolate mofetil for the prevention of acute rejection in primary cadaveric renal allograft recipients. U.S. renal transplant mycophenolate mofetil study group. Transplantation 1995, 60, 225-232. [CrossRef] [PubMed]

180. Hwang, J.; Lee, E.; Kim, J.; Seo, Y.; Lee, K.H.; Hong, J.W.; Gilad, A.A.; Park, H.; Choi, J. Effective delivery of immunosuppressive drug molecules by silica coated iron oxide nanoparticles. Colloids Surf. B Biointerfaces 2016, 142, 290-296. [CrossRef] [PubMed]

181. He, X.; Smeets, R.L.; Koenen, H.J.; Vink, P.M.; Wagenaars, J.; Boots, A.M.; Joosten, I. Mycophenolic acid-mediated suppression of human CD4+ T cells: More than mere guanine nucleotide deprivation. Am. J. Transpl. 2011, 11, 439-449. [CrossRef] [PubMed]

182. Liu, Z.; Yuan, X.; Luo, Y.; He, Y.; Jiang, Y.; Chen, Z.K.; Sun, E. Evaluating the effects of immunosuppressants on human immunity using cytokine profiles of whole blood. Cytokine 2009, 45, 141-147. [CrossRef] [PubMed] 
183. Fu, T.; Kong, Q.; Sheng, H.; Gao, L. Value of functionalized superparamagnetic iron oxide nanoparticles in the diagnosis and treatment of acute temporal lobe epilepsy on MRI. Neural Plast. 2016, 2016, 1-12. [CrossRef] [PubMed]

184. Rosillo-de la Torre, A.; Zurita-Olvera, L.; Orozco-Suárez, S.; Garcia Casillas, P.E.; Salgado-Ceballos, H.; Luna-Bárcenas, G.; Rocha, L. Phenytoin carried by silica core iron oxide nanoparticles reduces the expression of pharmacoresistant seizures in rats. Nanomedicine 2015, 10, 3563-3577. [CrossRef] [PubMed]

185. Lazarowski, A.; Ramos, A.J.; García-Rivello, H.; Brusco, A.; Girardi, E. Neuronal and glial expression of the multidrug resistance gene product in an experimental epilepsy model. Cell. Mol. Neurobiol. 2004, 24, 77-85. [CrossRef] [PubMed]

186. Attia, M.F.; Anton, N.; Khan, I.U.; Serra, C.A.; Messaddeq, N.; Jakhmola, A.; Vecchione, R.; Vandamme, T. One-step synthesis of iron oxide polypyrrole nanoparticles encapsulating ketoprofen as model of hydrophobic drug. Int. J. Pharm. 2016, 508, 61-70. [CrossRef] [PubMed]

187. Jia, Y.; Fan, M.; Chen, H.; Miao, Y.; Xing, L.; Jiang, B.; Cheng, Q.; Liu, D.; Bao, W.; Qian, B.; et al. Magnetic hyaluronic acid nanospheres via aqueous Diels-Alder chemistry to deliver dexamethasone for adipose tissue engineering. J. Colloid Interface Sci. 2015, 458, 293-299. [CrossRef] [PubMed]

188. Lafond, J.F.; Shimoji, M.; Ramaswamy, B.; Shukoor, M.I.; Malik, P.; Shapiro, B.; Depireux, D.A. Middle ear histopathology following magnetic delivery to the cochlea of prednisolone-loaded iron oxide nanoparticles in rats. Toxicol. Pathol. 2018, 46, 101-106. [CrossRef] [PubMed]

189. Hussein-Al-Ali, S.H.; El Zowalaty, M.E.; Hussein, M.Z.; Ismail, M.; Webster, T.J. Synthesis, characterization, controlled release, and antibacterial studies of a novel streptomycin chitosan magnetic nanoantibiotic. Int. J. Nanomed. 2014, 16, 549-557. [CrossRef]

190. El Zowalaty, M.E.; Hussein-Al-Ali, S.H.; Husseiny, M.I.; Geilich, B.M.; Webster, T.J.; Hussein, M.Z. The ability of streptomycin-loaded chitosan-coated magnetic nanocomposites to possess antimicrobial and antituberculosis activities. Int. J. Nanomed. 2015, 10, 3269-3274. [CrossRef] [PubMed]

191. Ivashchenko, O.; Jurga-Stopa, J.; Coy, E.; Peplinska, B.; Pietralik, Z.; Jurga, S. Fourier transform infrared and Raman spectroscopy studies on magnetite/Ag/antibiotic nanocomposites. Appl. Surf. Sci. 2016, 364, 400-409. [CrossRef]

192. Ivashchenko, O.; Coy, E.; Peplinska, B.; Jarek, M.; Lewandowski, M.; Załęski, K.; Warowicka, A.; Wozniak, A.; Babutina, T.; Jurga-Stopa, J.; et al. Influence of silver content on rifampicin adsorptivity for magnetite/Ag/rifampicin nanoparticles. Nanotechnology 2017, 28, 055603. [CrossRef] [PubMed]

193. Masadeh, M.M.; Karasneh, G.A.; Al-Akhras, M.A.; Albiss, B.A.; Aljarah, K.M.; Al-Azzam, S.I.; Alzoubi, K.H. Cerium oxide and iron oxide nanoparticles abolish the antibacterial activity of ciprofloxacin against gram positive and gram negative biofilm bacteria. Cytotechnology 2015, 67, 427-435. [CrossRef] [PubMed]

194. Bandara, H.M.; Nguyen, D.; Mogarala, S.; Osiñski, M.; Smyth, H.D. Magnetic fields suppress Pseudomonas aeruginosa biofilms and enhance ciprofloxacin activity. Biofouling 2015, 31, 443-457. [CrossRef] [PubMed]

195. Istrate, C.M.; Holban, A.M.; Grumezescu, A.M.; Mogoantă, L.; Mogoşanu, G.D.; Savopol, T.; Moisescu, M.; Iordache, M.; Vasile, B.S.; Kovacs, E. Iron oxide nanoparticles modulate the interaction of different antibiotics with cellular membranes. Rom. J. Morphol. Embryol. 2014, 55, 849-856. [PubMed]

196. Hussein-Al-Ali, S.H.; El Zowalaty, M.E.; Kura, A.U.; Geilich, B.; Fakurazi, S.; Webster, T.J.; Hussein, M.Z. Antimicrobial and controlled release studies of a novel nystatin conjugated iron oxide nanocomposite. Biomed. Res. Int. 2014, 2014, 651831. [CrossRef] [PubMed]

197. Maltas, E.; Ozmen, M.; Yildirimer, B.; Kucukkolbasi, S.; Yildiz, S. Interaction between ketoconazole and human serum albumin on epoxy modified magnetic nanoparticles for drug delivery. J. Nanosci. Nanotechnol. 2013, 13, 6522-6528. [CrossRef] [PubMed]

198. Niemirowicz, K.; Durnaś, B.; Tokajuk, G.; Głuszek, K.; Wilczewska, A.Z.; Misztalewska, I.; Mystkowska, J.; Michalak, G.; Sodo, A.; Watek, M.; et al. Magnetic nanoparticles as a drug delivery system that enhance fungicidal activity of polyene antibiotics. Nanomedicine 2016, 12, 2395-2404. [CrossRef] [PubMed]

199. Pelgrift, R.Y.; Friedman, A.J. Nanotechnology as a therapeutic tool to combat microbial resistance. Adv. Drug Deliv. Rev. 2013, 65, 1803-1815. [CrossRef] [PubMed]

200. Pan, X.; Redding, J.E.; Wiley, P.A.; Wen, L.; McConnell, J.S.; Zhang, B. Mutagenicity evaluation of metal oxide nanoparticles by the bacterial reverse mutation assay. Chemosphere 2010, 79, 113-116. [CrossRef] [PubMed] 
201. Saleh, N.B.; Chambers, B.; Aich, N.; Plazas-Tuttle, J.; Phung-Ngoc, H.N.; Kirisits, M.J. Mechanistic lessons learned from studies of planktonic bacteria with metallic nanomaterials: Implications for interactions between nanomaterials and biofilm bacteria. Front. Microbiol. 2015, 6, 677. [CrossRef] [PubMed]

202. Grumezescu, A.M.; Gestal, M.C.; Holban, A.M.; Grumezescu, V.; Vasile, B.S.; Mogoantă, L.; Iordache, F.; Bleotu, C.; Mogoșanu, G.D. Biocompatible $\mathrm{Fe}_{3} \mathrm{O}_{4}$ increases the efficacy of amoxicillin delivery against Gram-positive and Gram-negative bacteria. Molecules 2014, 19, 5013-5027. [CrossRef] [PubMed]

203. Wang, C.; Zhang, K.; Zhou, Z.; Li, Q.; Shao, L.; Hao, R.Z.; Xiao, R.; Wang, S. Vancomycin-modified $\mathrm{Fe}_{3} \mathrm{O}_{4} @ \mathrm{SiO}_{2} @ \mathrm{Ag}$ microflowers as effective antimicrobial agents. Int. J. Nanomed. 2017, 12, 3077-3094. [CrossRef] [PubMed]

204. Shah, S.T.; A Yehya, W.; Saad, O.; Simarani, K.; Chowdhury, Z.; A Alhadi, A.; Al-Ani, L.A. Surface functionalization of iron oxide nanoparticles with gallic acid as potential antioxidant and antimicrobial agents. Nanomaterials 2017, 7, 306. [CrossRef] [PubMed]

205. Borcherding, J.; Baltrusaitis, J.; Chen, H.; Stebounova, L.; Wu, C.M.; Rubasinghege, G.; Mudunkotuwa, I.A.; Caraballo, J.C.; Zabner, J.; Grassian, V.H.; et al. Iron oxide nanoparticles induce Pseudomonas aeruginosa growth, induce biofilm formation, and inhibit antimicrobial peptide function. Environ. Sci. Nano 2014, 1, 123-132. [CrossRef] [PubMed]

206. Haney, C.; Rowe, J.J.; Robinson, J.B. Spions increase biofilm formation by Pseudomonas aeruginosa. J. Biomater. Nanobiotechnol. 2012, 3, 508-518. [CrossRef]

207. Tokajuk, G.; Niemirowicz, K.; Deptula, P.; Piktel, E.; Ciesluk, M.; Wilczewska, A.Z.; Dabrowski, J.R.; Bucki, R. Use of magnetic nanoparticles as a drug delivery system to improve chlorhexidine antimicrobial activity. Int. J. Nanomed. 2017, 12, 7833-7846. [CrossRef] [PubMed]

208. Luo, D.; Shahid, S.; Hasan, S.M.; Whiley, R.; Sukhorukov, G.B.; Cattell, M.J. Controlled release of chlorhexidine from a HEMA-UDMA resin using a magnetic field. Dent. Mater. 2018, 34, 764-775. [CrossRef] [PubMed]

209. Morones, J.R.; Elechiguerra, J.L.; Camacho, A.; Holt, K.; Kouri, J.B.; Ramírez, J.T.; Yacaman, M.J. The bactericidal effect of silver nanoparticles. Nanotechnology 2005, 16, 2346-2353. [CrossRef] [PubMed]

210. Nel, A.E.; Mädler, L.; Velegol, D.; Xia, T.; Hoek, E.M.; Somasundaran, P.; Klaessig, F.; Castranova, V.; Thompson, M. Understanding biophysicochemical interactions at the nano-bio interface. Nat. Mater. 2009, 8, 543-557. [CrossRef] [PubMed]

211. Javanbakht, T.; Laurent, S.; Stanicki, D.; Wilkinson, K.J. Relating the surface properties of superparamagnetic iron oxide nanoparticles (SPIONs) to their bactericidal effect towards a biofilm of Streptococcus mutans. PLoS ONE 2016, 11, e0154445. [CrossRef] [PubMed]

212. Gao, L.; Liu, Y.; Kim, D.; Li, Y.; Hwang, G.; Naha, P.C.; Cormode, D.P.; Koo, H. Nanocatalysts promote Streptococcus mutans biofilm matrix degradation and enhance bacterial killing to suppress dental caries in vivo. Biomaterials 2016, 101, 272-284. [CrossRef] [PubMed]

213. Valdiglesias, V.; Kiliç, G.; Costa, C.; Fernández-Bertólez, N.; Pásaro, E.; Teixeira, J.P.; Laffon, B. Effects of iron oxide nanoparticles: Cytotoxicity, genotoxicity, developmental toxicity, and neurotoxicity. Environ. Mol. Mutagen. 2015, 56, 125-148. [CrossRef] [PubMed]

214. Patil, U.S.; Adireddy, S.; Jaiswal, A.; Mandava, S.; Lee, B.R.; Chrisey, D.B. In vitro/In vivo toxicity evaluation and quantification of iron oxide nanoparticles. Int. J. Mol. Sci. 2015, 16, 24417-24450. [CrossRef] [PubMed]

215. Sonmez, E.; Aydin, E.; Turkez, H.; Özbek, E.; Togar, B.; Meral, K.; Çetin, D.; Cacciatore, I.; Di Stefano, A. Cytotoxicity and genotoxicity of iron oxide nanoparticles: An in vitro biosafety study. Arch. Biol. Sci. 2016, 68, 41-50. [CrossRef]

216. Xu, H.L.; Mao, K.L.; Huang, Y.P.; Yang, J.J.; Xu, J.; Chen, P.P.; Fan, Z.L.; Zou, S.; Gao, Z.Z.; Yin, J.Y.; et al. Glioma-targeted superparamagnetic iron oxide nanoparticles as drug-carrying vehicles for theranostic effects. Nanoscale 2016, 8, 14222-14236. [CrossRef] [PubMed]

217. Lee, J.H.; Ju, J.E.; Kim, B.I.; Pak, P.J.; Choi, E.K.; Lee, H.S.; Chung, N. Rod-shaped iron oxide nanoparticles are more toxic than sphere-shaped nanoparticles to murine macrophage cells. Environ. Toxicol. Chem. 2014, 33, 2759-2766. [CrossRef] [PubMed]

218. Hong, S.C.; Lee, J.H.; Lee, J.; Kim, H.Y.; Park, J.Y.; Cho, J.; Lee, J.; Han, D.W. Subtle cytotoxicity and genotoxicity differences in superparamagnetic iron oxide nanoparticles coated with various functional groups. Int. J. Nanomed. 2011, 6, 3219-3231. [CrossRef] 
219. Feng, Q.; Liu, Y.; Huang, J.; Chen, K.; Huang, J.; Xiao, K. Uptake, distribution, clearance, and toxicity of iron oxide nanoparticles with different sizes and coatings. Sci. Rep. 2018, 8, 2082. [CrossRef] [PubMed]

220. Valdiglesias, V.; Fernández-Bertólez, N.; Kiliç, G.; Costa, C.; Costa, S.; Fraga, S.; Bessa, M.J.; Pásaro, E.; Teixeira, J.P.; Laffon, B. Are iron oxide nanoparticles safe? Current knowledge and future perspectives. J. Trace Elem. Med. Biol. 2016, 38, 53-63. [CrossRef] [PubMed]

221. Bellusci, M.; La Barbera, A.; Padella, F.; Mancuso, M.; Pasquo, A.; Grollino, M.G.; Leter, G.; Nardi, E.; Cremisini, C.; Giardullo, P.; et al. Biodistribution and acute toxicity of a nanofluid containing manganese iron oxide nanoparticles produced by a mechanochemical process. Int. J. Nanomed. 2014, 9, 1919-1929. [CrossRef]

222. Hajikarimi, Z.; Khoei, S.; Khoee, S.; Mahdavi, S.R. Evaluation of the cytotoxic effects of PLGA coated iron oxide nanoparticles as a carrier of 5-fluorouracil and mega-voltage X-ray radiation in DU145 prostate cancer cell line. IEEE Trans. Nanobiosci. 2014, 13, 403-408. [CrossRef] [PubMed]

223. Raji, M.A.; Amara, M.; Amoabediny, G.; Tajik, P.; Barin, A.; Magierowski, S.; Ghafar-Zadeh, E. Cytotoxicity of synthesized iron oxide nanoparticles: Toward novel biomarkers of colon cancer. Conf. Proc. IEEE Eng. Med. Biol. Soc. 2014, 2014, 6179-6182. [CrossRef] [PubMed]

224. Calero, M.; Gutiérrez, L.; Salas, G.; Luengo, Y.; Lázaro, A.; Acedo, P.; Morales, M.P.; Miranda, R.; Villanueva, A. Efficient and safe internalization of magnetic iron oxide nanoparticles: Two fundamental requirements for biomedical applications. Nanomedicine 2014, 10, 733-743. [CrossRef] [PubMed]

225. Sun, B.; Liu, R.; Ye, N.; Xiao, Z.D. Comprehensive evaluation of microRNA expression profiling reveals the neural signaling specific cytotoxicity of superparamagnetic iron oxide nanoparticles (SPIONs) through N-methyl-D-aspartate receptor. PLoS ONE 2015, 10, e0121671. [CrossRef] [PubMed]

226. Sadeghi, L.; Tanwir, F.; Yousefi Babadi, V. In vitro toxicity of iron oxide nanoparticle: Oxidative damages on Hep G2 cells. Exp. Toxicol. Pathol. 2015, 67, 197-203. [CrossRef] [PubMed]

227. Yalcin, S.; Khodadust, R.; Unsoy, G.; Garip, I.C.; Mumcuoglu, Z.D.; Gunduz, U. Synthesis and characterization of polyhydroxybutyrate coated magnetic nanoparticles: Toxicity analyses on different cell lines. Synth. React. Inorg. Met.-Org. Nano-Met. Chem. 2015, 45, 700-708. [CrossRef]

228. Cheng, K.K.; Chan, P.S.; Fan, S.; Kwan, S.M.; Yeung, K.L.; Wang, Y.X.; Chow, A.H.; Wu, E.X.; Baum, L. Curcumin-conjugated magnetic nanoparticles for detecting amyloid plaques in Alzheimer's disease mice using magnetic resonance imaging (MRI). Biomaterials 2015, 44, 155-172. [CrossRef] [PubMed]

229. Comănescu, M.V.; Mocanu, M.A.; Anghelache, L.; Marinescu, B.; Dumitrache, F.; Bădoi, A.D.; Manda, G. Toxicity of L-DOPA coated iron oxide nanoparticles in intraperitoneal delivery setting-Preliminary preclinical study. Rom. J. Morphol. Embryol. 2015, 56, 691-696. [PubMed]

230. Couto, D.; Sousa, R.; Andrade, L.; Leander, M.; Lopez-Quintela, M.A.; Rivas, J.; Freitas, P.; Lima, M.; Porto, G.; Porto, B.; et al. Polyacrylic acid coated and non-coated iron oxide nanoparticles are not genotoxic to human T lymphocytes. Toxicol. Lett. 2015, 234, 67-73. [CrossRef] [PubMed]

231. Ghasempour, S.; Shokrgozar, M.A.; Ghasempour, R.; Alipour, M. Investigating the cytotoxicity of iron oxide nanoparticles in in vivo and in vitro studies. Exp. Toxicol. Pathol. 2015, 67, 509-515. [CrossRef] [PubMed]

232. Liao, S.H.; Liu, C.H.; Bastakoti, B.P.; Suzuki, N.; Chang, Y.; Yamauchi, Y.; Lin, F.H.; Wu, K.C. Functionalized magnetic iron oxide/alginate core-shell nanoparticles for targeting hyperthermia. Int. J. Nanomed. 2015, 10, 3315-3328. [CrossRef]

233. Magdolenova, Z.; Drlickova, M.; Henjum, K.; Rundén-Pran, E.; Tulinska, J.; Bilanicova, D.; Pojana, G.; Kazimirova, A.; Barancokova, M.; Kuricova, M.; et al. Coating-dependent induction of cytotoxicity and genotoxicity of iron oxide nanoparticles. Nanotoxicology 2015, 9, 44-56. [CrossRef] [PubMed]

234. Venkatesan, K.; Rajan Babu, D.; Kavya Bai, M.P.; Supriya, R.; Vidya, R.; Madeswaran, S.; Anandan, P.; Arivanandhan, M.; Hayakawa, Y. Structural and magnetic properties of cobalt-doped iron oxide nanoparticles prepared by solution combustion method for biomedical applications. Int. J. Nanomed. 2015, 10, 189-198. [CrossRef]

235. Paolini, A.; Guarch, C.P.; Ramos-López, D.; de Lapuente, J.; Lascialfari, A.; Guari, Y.; Larionova, J.; Long, J.; Nano, R. Rhamnose-coated superparamagnetic iron-oxide nanoparticles: An evaluation of their in vitro cytotoxicity, genotoxicity and carcinogenicity. J. Appl. Toxicol. 2016, 36, 510-520. [CrossRef] [PubMed]

236. Bhandari, R.; Gupta, P.; Dziubla, T.; Hilt, J.Z. Single step synthesis, characterization and applications of curcumin functionalized iron oxide magnetic nanoparticles. Mater. Sci. Eng. C Mater. Biol. Appl. 2016, 67, 59-64. [CrossRef] [PubMed] 
237. Friedrich, R.P.; Zaloga, J.; Schreiber, E.; Tóth, I.Y.; Tombácz, E.; Lyer, S.; Alexiou, C. Tissue plasminogen activator binding to superparamagnetic iron oxide nanoparticle-covalent versus adsorptive approach. Nanoscale Res. Lett. 2016, 11, 297. [CrossRef] [PubMed]

238. Park, J.; Kadasala, N.R.; Abouelmagd, S.A.; Castanares, M.A.; Collins, D.S.; Wei, A.; Yeo, Y. Polymer-iron oxide composite nanoparticles for EPR-independent drug delivery. Biomaterials 2016, 101, 285-295. [CrossRef] [PubMed]

239. Rajiv, S.; Jerobin, J.; Saranya, V.; Nainawat, M.; Sharma, A.; Makwana, P.; Gayathri, C.; Bharath, L.; Singh, M.; Kumar, M.; et al. Comparative cytotoxicity and genotoxicity of cobalt (II, III) oxide, iron (III) oxide, silicon dioxide, and aluminum oxide nanoparticles on human lymphocytes in vitro. Hum. Exp. Toxicol. 2016, 35, 170-183. [CrossRef] [PubMed]

240. Jarockyte, G.; Daugelaite, E.; Stasys, M.; Statkute, U.; Poderys, V.; Tseng, T.C.; Hsu, S.H.; Karabanovas, V.; Rotomskis, R. Accumulation and toxicity of superparamagnetic iron oxide nanoparticles in cells and experimental animals. Int. J. Mol. Sci. 2016, 17, 1193. [CrossRef] [PubMed]

241. Song, X.; Gu, X.; Sun, H.; Fu, C.; Zhang, Y.; Dong, P. Biomimetic modification and in vivo safety assessment of superparamagnetic iron oxide nanoparticles. J. Nanosci. Nanotechnol. 2016, 16, 4100-4107. [CrossRef] [PubMed]

242. Huang, Y.; Mao, K.; Zhang, B.; Zhao, Y. Superparamagnetic iron oxide nanoparticles conjugated with folic acid for dual target-specific drug delivery and MRI in cancer theranostics. Mater. Sci. Eng. C Mater. Biol. Appl. 2017, 70, 763-771. [CrossRef] [PubMed]

243. Zhang, H.; Xia, J.; Pang, X.; Zhao, M.; Wang, B.; Yang, L.; Wan, H.; Wu, J.; Fu, S. Magnetic nanoparticle-loaded electrospun polymeric nanofibers for tissue engineering. Mater. Sci. Eng. C Mater. Biol. Appl. 2017, 73, 537-543. [CrossRef] [PubMed]

244. Sohrabijam, Z.; Saeidifar, M.; Zamanian, A. Enhancement of magnetofection efficiency using chitosan coated superparamagnetic iron oxide nanoparticles and calf thymus DNA. Colloids Surf. B Biointerfaces 2017, 152, 169-175. [CrossRef] [PubMed]

245. Moise, S.; Céspedes, E.; Soukup, D.; Byrne, J.M.; El Haj, A.J.; Telling, N.D. The cellular magnetic response and biocompatibility of biogenic zinc- and cobalt-doped magnetite nanoparticles. Sci. Rep. 2017, 7, 39922. [CrossRef] [PubMed]

246. Patel, S.; Jana, S.; Chetty, R.; Thakore, S.; Singh, M.; Devkar, R. Toxicity evaluation of magnetic iron oxide nanoparticles reveals neuronal loss in chicken embryo. Drug Chem. Toxicol. 2017, 27, 1-8. [CrossRef] [PubMed]

247. Salimi, M.; Sarkar, S.; Fathi, S.; Alizadeh, A.M.; Saber, R.; Moradi, F.; Delavari, H. Biodistribution, pharmacokinetics, and toxicity of dendrimer-coated iron oxide nanoparticles in BALB/c mice. Int. J. Nanomed. 2018, 13, 1483-1493. [CrossRef] [PubMed]

248. Shevtsov, M.; Nikolaev, B.; Marchenko, Y.; Yakovleva, L.; Skvortsov, N.; Mazur, A.; Tolstoy, P.; Ryzhov, V.; Multhoff, G. Targeting experimental orthotopic glioblastoma with chitosan-based superparamagnetic iron oxide nanoparticles (CS-DX-SPIONs). Int. J. Nanomed. 2018, 13, 1471-1482. [CrossRef] [PubMed]

249. Apopa, P.L.; Qian, Y.; Shao, R.; Guo, N.L.; Schwegler-Berry, D.; Pacurari, M.; Porter, D.; Shi, X.; Vallyathan, V.; Castranova, V.; et al. Iron oxide nanoparticles induce human microvascular endothelial cell permeability through reactive oxygen species production and microtubule remodeling. Part. Fibre Toxicol. 2009, 6, 1. [CrossRef] [PubMed]

250. Singh, N.; Jenkins, G.J.; Asadi, R.; Doak, S.H. Potential toxicity of superparamagnetic iron oxide nanoparticles (SPION). Nano Rev. 2010, 1, 5358. [CrossRef] [PubMed]

251. Yarjanli, Z.; Ghaedi, K.; Esmaeili, A.; Rahgozar, S.; Zarrabi, A. Iron oxide nanoparticles may damage to the neural tissue through iron accumulation, oxidative stress, and protein aggregation. BMC Neurosci. 2017, 18, 51. [CrossRef] [PubMed]

252. Dwivedi, S.; Siddiqui, M.A.; Farshori, N.N.; Ahamed, M.; Musarrat, J.; Al-Khedhairy, A.A. Synthesis, characterization and toxicological evaluation of iron oxide nanoparticles in human lung alveolar epithelial cells. Colloids Surf. B Biointerfaces 2014, 122, 209-215. [CrossRef] [PubMed]

253. Wei, Y.; Zhao, M.; Yang, F.; Mao, Y.; Xie, H.; Zhou, Q. Iron overload by superparamagnetic iron oxide nanoparticles is a high risk factor in cirrhosis by a systems toxicology assessment. Sci. Rep. 2016, 6, 29110. [CrossRef] [PubMed] 
254. Mahmoudi, M.; Simchi, A.; Imani, M.; Milani, A.S.; Stroeve, P. An in vitro study of bare and poly(ethylene glycol)-co-fumaratecoated superparamagnetic iron oxide nanoparticles: A new toxicity identification procedure. Nanotechnology 2009, 20, 225104. [CrossRef] [PubMed]

255. Mahmoudi, M.; Simchi, A.; Imani, M.; Shokrgozar, M.A.; Milani, A.S.; Häfeli, U.O.; Stroeve, P. A new approach for the in vitro identification of the cytotoxicity of superparamagnetic iron oxide nanoparticles. Colloids Surf. B Biointerfaces 2010, 75, 300-309. [CrossRef] [PubMed]

256. Sanganeria, P.; Sachar, S.; Chandra, S.; Bahadur, D.; Ray, P.; Khanna, A. Cellular internalization and detailed toxicity analysis of protein-immobilized iron oxide nanoparticles. J. Biomed. Mater. Res. B Appl. Biomater. 2015, 103, 125-134. [CrossRef] [PubMed]

257. Pöttler, M.; Staicu, A.; Zaloga, J.; Unterweger, H.; Weigel, B.; Schreiber, E.; Hofmann, S.; Wiest, I.; Jeschke, U.; Alexiou, C.; et al. Genotoxicity of superparamagnetic iron oxide nanoparticles in granulosa cells. Int. J. Mol. Sci. 2015, 16, 26280-26290. [CrossRef] [PubMed]

258. Zhang, X.; Zhang, H.; Liang, X.; Zhang, J.; Tao, W.; Zhu, X.; Chang, D.; Zeng, X.; Liu, G.; Mei, L. Iron oxide nanoparticles induce autophagosome accumulation through multiple mechanisms: Lysosome impairment, mitochondrial damage, and ER stress. Mol. Pharm. 2016, 13, 2578-2587. [CrossRef] [PubMed]

259. Pongrac, I.M.; Pavičić, I.; Milić, M.; Brkić Ahmed, L.; Babič, M.; Horák, D.; Vinković Vrček, I.; Gajović, S. Oxidative stress response in neural stem cells exposed to different superparamagnetic iron oxide nanoparticles. Int. J. Nanomed. 2016, 11, 1701-1715. [CrossRef]

(C) 2018 by the authors. Licensee MDPI, Basel, Switzerland. This article is an open access article distributed under the terms and conditions of the Creative Commons Attribution (CC BY) license (http://creativecommons.org/licenses/by/4.0/). 